\title{
Role of sweeteners on temporality and bar hardening of protein bars
}

\author{
H. R. M. Keefer, ${ }^{1}$ S. Nishku, ${ }^{1}$ P. D. Gerard,${ }^{2}$ and M. A. Drake ${ }^{1 *}$ \\ ${ }^{1}$ Department of Food, Bioprocessing and Nutrition Sciences, Southeast Dairy Foods Research Center, Box 7624, North Carolina State University, \\ Raleigh 27695-7624 \\ ${ }^{2}$ School of Mathematical and Statistical Sciences, Clemson University, Clemson, SC 29634
}

\begin{abstract}
Protein bars are one product that meet consumer demands for a low-carbohydrate, high-protein food. With such a large market for protein bars, producers need to find the correct texture and sweetness levels to satisfy consumers while still delivering a high-protein, low-carbohydrate bar. In the bar industry, bar hardening is a major concern, and currently the effects of non-nutritive sweeteners on bar hardening is unknown. Due to the negative implications of bar hardening, it is important to investigate the sweetener-protein relationship with bar hardening. The objective of this study was to characterize the effects of sweetener and protein source on flavor, texture, and shelf life of high-protein, low-carbohydrate bars. The iso-sweet concentration of sweeteners (sucralose, sucrose, monk fruit, stevia, and fructose) in pea protein (PP), milk protein (MP) and whey protein isolate (WPI) bars were established using magnitude estimation scaling and 2-alternative forcedchoice testing. Descriptive analysis and temporal checkall-that-apply methods were then applied to determine flavor and temporal differences between the protein bars. Finally, an accelerated shelf life study was completed to understand how sweetener and protein types affect the shelf life of protein bars. The 15 protein bars formulated at iso-sweet concentration were all stored at $35^{\circ} \mathrm{C}$ and $55 \%$ humidity for $35 \mathrm{~d}$, and measurements were taken every $7 \mathrm{~d}$, beginning at $\mathrm{d} 1$ (d 1, 7, 14, 21, 28, and 35). Bars made with MP required significantly less sweetener, compared with PP and WPI, to reach equal sweetness. Bars sweetened with stevia or monk fruit had distinct bitter and metallic tastes, and sucralose had a low metallic taste. Bars made with WPI were the most cohesive, and PP and WPI bars were more bitter and metallic compared with MP bars. Bars made with WPI and fructose were initially the hardest, but after d 14 they scored at parity with PP sucrose.
\end{abstract}

Received December 1, 2019.

Accepted March 2, 2020.

*Corresponding author: mdrake@ncsu.edu
There were no significant differences among bars in terms of hardness by d 21. Bars made with WPI were consistently denser at all time points than bars made with PP or MP. Bars made with PP were the driest and least cohesive and had the fastest rate of breakdown in the study. Non-nutritive sweeteners did not have a negative effect on bar hardness in low-carbohydrate, high-protein bars. Findings from this study can be applied to commercially produced protein bars for naturally sweetened bars with different protein types without negative effects on protein bar texture.

Key words: protein bar, sugar reduction, hardening

\section{INTRODUCTION}

Currently, consumers desire low-carbohydrate, highprotein foods, and protein bars are one food product that meet this demand. In 2016, the protein bar industry was valued at over US $\$ 837$ million, with several companies competing for a share of the market (Mordor Intelligence, 2018). With high competition and so many options for consumers, companies have to find the correct texture and sweetness to satisfy consumers while still delivering a high-protein, low-carbohydrate bar (Guinard and Mazzucchelli, 1996; Imtiaz et al., 2012). In the bar industry, many sources of plant and animal proteins are available, and the type of protein used can have a significant effect on bar texture (Imtiaz et al., 2012). The most common bar protein sources are soy and whey protein (Mordor Intelligence, 2018). Other proteins are available, and it is important to investigate the implications of using different protein sources on the texture and sweetness of protein bars (Imtiaz et al., 2012).

To make a low-carbohydrate bar while preserving sweetness, non-nutritive sweeteners can be substituted for sugar to reduce calories and to satisfy consumers (Yebra-Biurrun, 2005; Behrens et al., 2011). Past studies with other foods have shown that sugar can be reduced by 25 to $30 \%$ while maintaining consumer acceptance (Cadena et al., 2012; Li et al., 2015; McCain et al., 2018). Sugar contributes 4 calories per gram, whereas non-nutritive sweeteners can be 30 to 20,000 times 
sweeter than sugar, which allows for less to be added for a similar sweetness, with fewer calories (Mitchell, 2007; Zygler et al., 2011). Although non-nutritive sweeteners are great alternatives to sugar, several recent studies have reported that sugar substitution is an inherently difficult task (Parker et al., 2018; Wagoner et al., 2018). Food structure, specifically texture, has a significant effect on consumer enjoyment, and sugar substitution can be difficult because sucrose is a key ingredient in providing texture (Wilkinson et al., 2000; Cardoso and Bolini, 2008; Silcock, 2017). Specifically, substituting non-nutritive sweeteners to reduce calories in protein bars has major textural implications. In the protein bar industry, where bar hardening is a major concern, the effects of non-nutritive sweeteners on bar hardening are unknown. Bar hardening occurs when the protein matrix hardens due to age, and this problem is only intensified as protein content increases (Wilkinson et al., 2000). Once protein bars harden, the resulting texture can lead to consumer rejection or avoidance of the protein bars (Wilkinson et al., 2000; McMahon et al., 2009). Bar hardening negatively effects profit margins of companies and is a major issue for the bar industry.

Sugar substitution using non-nutritive sweeteners is also difficult because none of the non-nutritive sweeteners on the market are able to perfectly match the temporality of sucrose (Lawless and Heymann, 2010; Palazzo et al., 2011; Morais et al., 2014). Due to the negative implications of bar hardening, it is important to investigate the sweetener-protein relationship to bar hardening. To compare the effects of bar hardening and the flavor implications of each sweetener on a protein bar, the iso-sweet concentration or sweetness equivalence must first be determined. This is the amount of non-nutritive sweetener or sugar substitute needed to reach sweetness equivalence with a sucrose target. Magnitude estimation scaling (MES), followed by descriptive analysis and 2-alternative forced-choice (2-AFC) testing, is one set of methods to confirm sweet taste equivalency (Cardello et al., 1999; Lawless and Heymann, 2010; Li et al., 2015; Parker et al., 2018). Temporal methodologies can then be used to characterize differences between products over time (Palazzo et al., 2011; Zorn et al., 2014; Azevedo et al., 2015). Additionally, natural sweeteners have different flavor profiles from sucrose, and temporally documenting the presence of other basic tastes and temporality of sweet taste is important for the success of these natural non-nutritive sweeteners in foods (Parker et al., 2018). Previous research has reported that protein product label claims of "naturally sweetened" and "low carbohydrate" content are important to consumers and therefore important to investigate in regards to protein bars (Gerdes, 2012; Oltman et al., 2015; Harwood and Drake, 2019). Sev- eral studies have investigated bar hardening, but to our knowledge, no study has yet investigated how the addition of alternative sweeteners to protein bars affects the sensory and textural properties of protein bars. The objective of this study was to characterize the influence of sweetener and protein source on flavor, texture, and shelf life of high-protein low-carbohydrate bars.

\section{MATERIALS AND METHODS}

\section{Bar Preparation}

A model protein bar system consisting of a protein source, shortening, fiber, and sweetener was used. Three different protein sources, currently used in bar formulations, were used: whey protein isolate (BarFlex 191; Glanbia Nutritionals, Twin Falls, ID; $85.7 \%$ protein), milk protein isolate (BarPro 585, Glanbia Nutritionals; $81.7 \%$ protein), and pea protein (BarHarvest 801, Glanbia Nutritionals; $84.8 \%$ protein). All 3 protein powders were obtained as 22-kg lots and stored at $-80^{\circ} \mathrm{C}$ throughout the duration of the study. The sweeteners used were sucrose (India Tree caster sugar, Seattle, WA), liquid sucrose (Kelly's Delight liquid sugar, Woodway, TX), fructose (Krystar 300, Tate and Lyle, Decatur, IL), sucralose (Bulk Ingredients, Henderson, NV), monk fruit extract (Purefruit Select monk fruit extract, Tate and Lyle), and stevia leaf extract (Tasteva stevia sweetener, Tate and Lyle). Vegetable shortening was purchased from a local grocery store (Crisco, the J. M. Smucker Company, Orrville, OH). Fiber was purchased from BioNeutra (Vitafiber; Edmonton, AB, Canada). Bars were prepared in 500-g batches for MES and temporal studies and 2,600-g batches for the bar hardening study. Bars contained 15 $\mathrm{g}$ of protein per $62 \mathrm{~g}$ serving.

All ingredients were combined into a stainless steel bowl and hand mixed for approximately 3 to $4 \mathrm{~min}$ until a soft dough was formed (Table 1; McMahon et al., 2009). Fiber was adjusted to account for difference in mass when using non-nutritive sweeteners (Table 1). Bars were then rolled out to approximately $10-\mathrm{mm}$ thickness and cut into $80-\mathrm{mm}-$ long by $40-\mathrm{mm}-$ wide squares. Each 500-g batch yielded about 9 bars at these dimensions. All sensory testing was approved as exempt by the North Carolina State University Institutional Review Board for human subjects (Raleigh, NC). A pool of 20 descriptive analysis panelists with a minimum of $40 \mathrm{~h}$ of training and a range of descriptive analysis experience is maintained at North Carolina State University. Different groups of these panelists performed temporal check-all-that-apply (TCATA), descriptive analysis of flavor or sweet taste, and descriptive analysis of texture. 
Table 1. Formulation of protein bars (500-g batch) for sweeteners and protein types (in g) at iso-sweet taste intensity ${ }^{1}$

\begin{tabular}{|c|c|c|c|c|c|c|c|c|c|c|c|}
\hline $\begin{array}{l}\text { Milk } \\
\text { protein }\end{array}$ & $\begin{array}{l}\text { Whey } \\
\text { protein }\end{array}$ & $\begin{array}{c}\text { Pea } \\
\text { protein }\end{array}$ & $\begin{array}{c}\text { VitaFiber } \\
\text { DP3 }\end{array}$ & $\begin{array}{l}\text { Vegetable } \\
\text { shortening }\end{array}$ & Fructose & $\begin{array}{l}\text { Monk } \\
\text { fruit }\end{array}$ & Stevia & Sucralose & Sucrose & $\begin{array}{l}\text { Liquid } \\
\text { sucrose }\end{array}$ & $\begin{array}{c}\text { Water } \\
\text { activity }\left(\mathrm{a}_{\mathrm{w}}\right)\end{array}$ \\
\hline 145.0 & - & - & 230.6 & 80.0 & 44.434 & - & - & - & - & & 0.680 \\
\hline- & 145.0 & - & 201.7 & 80.0 & 73.256 & - & - & - & - & & 0.619 \\
\hline 145.0 & - & - & 274.4 & 80.0 & - & 0.575 & - & - & - & & 0.764 \\
\hline - & 145.0 & & 273.8 & 80.0 & - & 1.235 & - & - & - & & 0.742 \\
\hline - & - & 145.0 & 273.0 & 80.0 & - & 2.002 & - & - & - & & 0.751 \\
\hline 145.0 & - & - & 274.8 & 80.0 & - & - & - & 0.182 & - & & 0.759 \\
\hline- & 145.0 & - & 274.3 & 80.0 & - & - & - & 0.692 & - & & 0.725 \\
\hline - & - & 145.0 & 274.3 & 80.0 & - & - & - & 0.661 & - & & 0.760 \\
\hline 145.0 & - & - & 191.7 & 80.0 & - & - & - & - & 41.662 & 41.662 & 0.752 \\
\hline- & 145.0 & - & 120.6 & 80.0 & - & - & - & - & 77.189 & 77.189 & 0.727 \\
\hline - & - & 145.0 & 110.7 & 80.0 & - & - & - & - & 82.135 & 82.135 & 0.735 \\
\hline
\end{tabular}

${ }^{1}$ Bars were formulated at $15 \mathrm{~g}$ of protein per 62 -g serving. Bars were formulated to sweet taste equivalency to a $10 \% \mathrm{wt} /$ vol sucrose solution. VitaFiber: BioNeutra, Edmonton, AB, Canada.

\section{Selection of Iso-Sweet Taste Intensity from Protein Bars}

A preliminary sensory assessment of 12 commercial protein bars with various protein sources, protein loads, and sweeteners was conducted to determine a target sweet taste intensity for model bars. Target sweetness intensity of a $10 \%$ (wt/vol) sucrose solution was selected. Power functions for sweeteners were generated using MES in whey protein isolate (WPI), pea protein $(\mathbf{P P})$, and milk protein (MP) bars (Lawless and Heymann, 2010). The experimental design consistent of 5 sweeteners (fructose, sucrose, monk fruit, sucralose, and stevia) and 3 protein sources (pea, milk, and whey protein) for a total of 15 distinct protein bars. Panelists (n $=9 ; 5$ women and 4 men, ages 22 to $28 \mathrm{yr}$ ) participated in $10 \mathrm{~h}$ of MES training until they were able to demonstrate replicable ratio scaling with a range of sweetened solutions and WPI model bars before data collection (Meilgaard et al., 2016; Parker et al., 2018). The MES scaling method was used to create power function curves using $10 \%$ (wt/vol) sucrose solution as a reference intensity of 100 , and scale anchors of 5 and $20 \%$ (wt/vol) sucrose solutions representing intensities of 50 and 200, respectively. Panelists were instructed to refer to these references as they tasted each bar. Samples were served at $21^{\circ} \mathrm{C}$ in 120 -mL lidded soufflé cups with a random 3-digit code. Each MES series contained 7 bars, ranging from just noticeable sweetness to up to twice as sweet as the reference solution, and a step factor of 1.4 for sweetener concentration was used. Samples were randomized in each session, and only 1 MES series was evaluated per session. A 5-min rest period was enforced between samples, and panelists were instructed to rinse with deionized water. Paper ballots were used, and results were collected in triplicate.

The iso-sweet point for each protein type and each sweetener determined by MES was confirmed using descriptive analysis (described subsequently) and a directional paired comparison test (2-AFC; ASTM, 2008; Parker et al., 2018). Bars were presented in lidded 120 -mL soufflé cups with 3 -digit codes, using a balanced presentation order. Consumers for 2-AFC were recruited from the university community. Consumers (n $=40$ ) were instructed to taste each protein bar against the sucrose control protein bar in the order presented. Panelists selected the sample they believed was sweeter. A 3-min rest period was enforced between each set of samples, during which panelists were instructed to rinse their mouth with deionized water and take a bite of an unsalted cracker. No more than two 2-AFC tests were conducted in one session. Data for 2-AFC testing were collected on iPads (Apple Inc., Cupertino, CA) using Compusense Cloud (Compusense, Guelph, Canada).

\section{Descriptive Analysis of Iso-Sweet Taste and Descriptive Analysis of Flavor Following MES and Before 2-AFC Tests}

To confirm the iso-sweet point in protein bars for each sweetener, 6 trained panelists $(\mathrm{n}=6 ; 4$ women and 2 men, ages 24 to $56 \mathrm{yr}$ ) performed descriptive analyses (Meilgaard et al., 2016). Each panelist had more than $100 \mathrm{~h}$ of training using the 0 - to 15 -point Spectrum universal intensity scale (Meilgaard et al., 2016) and participated in an additional $20 \mathrm{~h}$ of training on protein bars with different sweeteners before the evaluation. Descriptive analysis of sweet taste was 
conducted on all protein bars sweetened with sucrose, fructose, sucralose, monk fruit, and stevia in the 3 different protein types (MP, WPI, PP). Bars were served at $21^{\circ} \mathrm{C}$ in lidded $120-\mathrm{mL}$ soufflé cups labeled with random 3-digit codes. A 5-min rest was enforced between samples. Each sample was evaluated by each panelist in duplicate, and no more than 5 bars were evaluated in a session. Paper ballots were used.

Descriptive analysis of bar flavor attributes was conducted following confirmation of iso-sweet taste intensity (Table 2). Bars were evaluated in triplicate by a trained descriptive panel (6 women and 2 men, ages 22 to $55 \mathrm{yr}$ ). Each panelist had more than $100 \mathrm{~h}$ of training using the 0- to 15-point Spectrum universal intensity scale and participated in an additional $20 \mathrm{~h}$ of training on protein bars with different sweeteners before the evaluation (Meilgaard et al., 2016). Bars were served in the same fashion as for descriptive analysis for sweet taste. A 5-min rest was enforced between samples.

\section{Temporal Check All That Apply}

Protein bars formulated to iso-sweetness were evaluated via TCATA. This temporal method was used to document how the flavor and taste intensities of the bars changed with the different protein sources and sweeteners (Ott et al., 1991; Hanger et al., 1996; Fujimaru et al., 2012). Bars were cut into 10-g aliquots and presented in lidded 120-mL soufflé cups labeled with 3 -digit codes. The protein bars were evaluated at $21^{\circ} \mathrm{C}$. All TCATA panelists $(\mathrm{n}=9 ; 6$ women and 3 men, ages 23 to $30 \mathrm{yr}$ ) had prior descriptive analysis experience ( $>40 \mathrm{~h}$ each) and participated in two 30-min instruction and practice sections for TCATA before beginning data collection. Attributes scored were sweet aromatic and cardboard flavors, sweet taste, bitter taste, metallic taste, cohesiveness, adhesiveness, and astringency.

Data were collected in quadruplicate over 8 sessions on iPads using the TCATA method in Compusense Cloud. In each session, each panelist evaluated a random presentation of 5 protein bars. Temporal evaluations of each protein bar were performed over the course of 192 $\mathrm{s}$, and panelists were allowed unlimited selection and deselection of all attributes perceived at any point over the course of evaluation (Ares et al., 2015; Castura et al., 2016). Panelists were instructed to place the entire sample in-mouth and press Start for an initial profiling of flavor attributes, mouthfeel, and basic tastes from

Table 2. Flavor and texture lexicon for protein bars

\begin{tabular}{|c|c|}
\hline Attribute & Definition \\
\hline \multicolumn{2}{|l|}{ Flavor } \\
\hline Sweet aromatic & $\begin{array}{l}\text { Sweet aromatic associated with grains such as oatmeal. Quaker oatmeal (Quaker Oats Company, Chicago, IL), } \\
50 \mathrm{~g} \text {, soaked in } 500 \mathrm{~mL} \text { of water. }\end{array}$ \\
\hline Cardboard & $\begin{array}{l}\text { Aromatics associated with wet cardboard and brown paper. } 2 \mathrm{~cm} \times 2 \mathrm{~cm} \text { piece of brown paper bag boiled in } \\
\text { water for } 30 \mathrm{~min} \text {. }\end{array}$ \\
\hline Milky & Aromatics associated with milk. 1\% fat HTST pasteurized milk. \\
\hline Sulfurous & Aromatics associated with sulfurous compounds. Boiled mashed egg. Hydrogen sulfide. \\
\hline Green pepper/pyrazine & $\begin{array}{l}\text { Aromatics associated with freshly cut green bell peppers. Methoxy pyrazines }(5 \mu \mathrm{g} / \mathrm{kg}) \text {; freshly cut bell } \\
\text { pepper. }\end{array}$ \\
\hline Fecal & Aromatic associated with complex protein decomposition. Indole, skatole (20 mg/kg). \\
\hline Tortilla & $\begin{array}{l}\text { Aromatic associated with cornmeal. Fresh white corn tortillas, Tostitos brand tortilla chips (Frito-Lay, Casa } \\
\text { Grande, AZ). }\end{array}$ \\
\hline Sweet taste & Basic taste elicited by sweeteners. \\
\hline Bitter taste & Basic taste elicited by various compounds including caffeine and quinine. \\
\hline First-bite hardness & $\begin{array}{l}\text { Force required to bite completely through the sample with the front teeth. Cream cheese }=1 \text {, Velveeta }(\text { Kraft } \\
\text { Foods, Chicago, IL) }=2 \text {, carrot slice }=11 \text {. }\end{array}$ \\
\hline $\begin{array}{l}\text { Denseness in mouth } \\
\text { (1 to } 2 \text { compressions) }\end{array}$ & $\begin{array}{l}\text { Compactness of the cross-section after } 1-2 \text { compressions. Cool Whip (Kraft Foods) }=0.5 \text {, Oscar Meyer brand } \\
\text { hot dog }(\text { Kraft Foods })=9 \text {, fruit jellies }=13 .\end{array}$ \\
\hline Cohesiveness & Degree to which the sample is in a bolus at 3 to 4 chews. Carrots $=2$, processed cheese $=9$ \\
\hline Rate of breakdown & How slow or fast the sample breaks down. Slow $=$ low number, fast $=$ high number. \\
\hline Adhesiveness & Degree to which sample sticks to any of the mouth surfaces throughout mastication. \\
\hline Tooth pack & Degree to which the sample packs in and around the teeth. Fruit jellies $=13$ \\
\hline No. of chews & $\begin{array}{l}\text { Count the number of chews required to get a three-quarter-inch }(1.9 \mathrm{~cm}) \text { square masticated to a state ready to } \\
\text { swallow (varies for each panelist). }\end{array}$ \\
\hline
\end{tabular}


0 to $20 \mathrm{~s}$. The panelists were then instructed to expectorate the sample at $20 \mathrm{~s}$, followed by an aftertaste evaluation of flavor attributes and basic tastes from 20 to $192 \mathrm{~s}$. Panelists underwent an enforced 5-min rest time between each sample and were instructed to rinse their mouths with deionized water before beginning the next sample.

\section{Bar Hardening and Color}

Bars were placed in labeled moisture-barrier pouches (Mylar, Sorbent Systems, Los Angeles, CA) and heatsealed. Bars were approximately $80 \mathrm{~mm}$ long by $40 \mathrm{~mm}$ wide and $10 \mathrm{~mm}$ thick, and 1 bar was placed in each pouch. Bars were stored at $35^{\circ} \mathrm{C}$ and $55 \%$ humidity (in cabinet) for $35 \mathrm{~d}$ for accelerated shelf-life testing in a Metro C 5 Series 3 Cabinet (Metro, Alton, IL). Temperature and humidity were confirmed using an Extech RH300 humidity meter (Extech Instruments, Waltham, MA). Accelerated shelf-life testing of $42 \mathrm{~d}$ corresponds to approximately 12 -mo storage at $21^{\circ} \mathrm{C}$, so $35 \mathrm{~d}$ corresponds to approximately 10-mo storage (Li et al., 2008). Measurements were taken every $7 \mathrm{~d}$ beginning at $\mathrm{d} 1$ (d 1, 7, 14, 21, 28, and 35).

Hardness was measured as the maximum load recorded during 7.5-mm penetration of a knife blade (Instron 5542 Universal Testing Machine, Instron, Norwood, MA) at a speed of $1 \mathrm{~mm} / \mathrm{s}$ into the bar (Li et al., 2008; McMahon et al., 2009). Bars were laid on the platform, and a hardness test was performed at 3 locations along each bar. Four replications were performed at each time point. An average hardness value was calculated by using the peak force $(g)$ of the force-versus-time graph $(\mathrm{Li}$ et al., 2008).

To measure color differences between the bars, Hunter L and $\mathrm{a}$, and Commission Internationale de l'Eclairage (CIE) b* values were measured on the bars at each time point (d 1, 7, 14, 21, 28, and 35) using an Ultra Scan Pro Spectrophotometer (Hunter Associates Laboratory Inc., Reston, VA). Luminosity (L) measures the degree of lightness from dark (0) to light (100), a measures the degree of redness defined by a positive number or greenness defined by a negative number, and $b^{*}$ measures the degree of yellowness defined by a positive number or blueness defined by a negative number (Quiñones et al., 1997; Cheng et al., 2018). Hunter values and CIE values were computed from the reflectance data in the range of 360 to $750 \mathrm{~nm}$ at $5-\mathrm{nm}$ intervals, Illuminant A with a 10-degree observer angle.

\section{Descriptive Analysis of Bar Texture}

Protein bars were evaluated by a trained sensory texture panel ( 8 female panelists, ages 40 to $55 \mathrm{yr}$ ).
Each panelist had more than $200 \mathrm{~h}$ of texture profiling experience using a 0 - to 15 -point product-specific texture scale. Five 2 -h training sessions were conducted to assess and calibrate on the texture attributes of commercial and experimental protein bars. During the training sessions, panelists generated and practiced with the identified attributes (Table 2). Moisture barrier pouches labeled with a random 3-digit code were presented to each panelist at $21^{\circ} \mathrm{C}$. For each session, panelists were presented with 1 protein bar and 1 bar texture reference with attribute intensities previously defined by the panel in the training session as a warmup. Each panelist evaluated each sample in quadruplicate in a randomized balanced block design from 2 physical replications of bar manufacture. A 5-min rest was enforced between each sample. Paper ballots were used, and no more than 5 bars were evaluated in a session.

\section{Statistical Analysis}

Power curves for sweet taste intensity were created using XLSTAT version 19.5.2018 (Addinsoft, New York, NY) and constructed by plotting the logarithm of the geometric mean of the average response at each sweetness concentration level against the logarithm of the sample sweetener concentration (ASTM, 2012; Parker et al., 2018). The iso-sweet concentrations determined from the power curves were then confirmed using the minimum number of "correct" judgments for significance through 2-AFC testing ( $\alpha=0.05$; ASTM, 2008; Meilgaard et al., 2016). A 2-way ANOVA (protein type $\times$ sweetener concentration) was conducted to determine these effects on the slopes of the iso-sweet power functions $(\alpha=0.05)$. Descriptive analysis data were evaluated via ANOVA, with Fisher's least significant difference test to determine means separation $(\alpha$ $=0.05$; Addinsoft).

Temporal data were analyzed using the smoothing and statistical analysis of TCATA data conducted in the tempR package in $\mathrm{R}$ version 3.4.0 (Castura et al., 2016). Comparisons between protein bar types were made at each second of evaluation using 2-sided Fisher's exact test. Citation proportions and differences were graphed using XLSTAT version 19.5.2018 (Addinsoft). For bar hardening, due to a 3-way interaction between protein, sweetener, and time point, separate analyses were performed for each day. Linear mixed model analyses were conducted, with sugar source, protein source, and their interaction as fixed effects. Random effects included batch and interactions between batch and sweetener and batch and protein, as well as the 3-way interaction between batch, sugar source, and protein source. The mixed procedure in SAS version 9.4 (SAS Institute, 

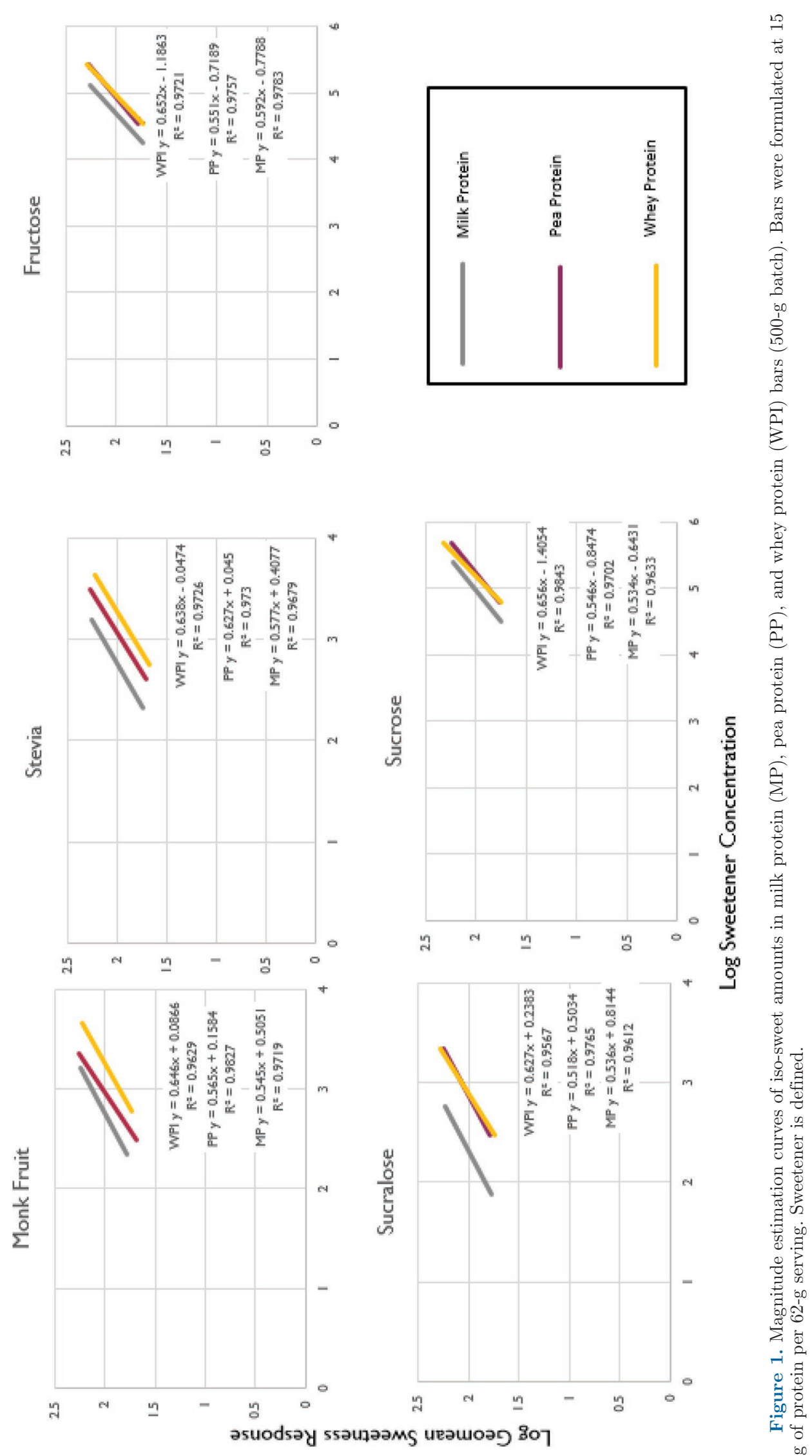
Cary, NC) was used, with differences in least squares means investigated. All statistical analyses were performed at $95 \%$ confidence level.

\section{RESULTS}

\section{Magnitude Estimation Scaling}

Consistent with previous studies, MES results and power function curves established that sucralose was the most potent sweetener, followed by monk fruit, stevia, and fructose (Cardello et al., 1999; Kim and Kinghorn, 2002; Wagoner et al., 2018; Figure 1). As expected, non-nutritive sweeteners required smaller amounts than did fructose to reach equivalency to $10 \%$ (wt/vol) sucrose based on the power function slope curves (Table 3, Figure 1). More importantly, different protein types required different sweetener amounts to reach iso-sweet concentration (Table 1). More sweetener was needed for bars with PP or WPI than for MP (Table 3, Figure 1).
Table 3. Iso-sweet sweetener slopes from magnitude estimation scaling with each sweetener in milk protein, pea protein, and whey protein bars $(500-\mathrm{g} \text { batch })^{1}$

\begin{tabular}{llll}
\hline Sweetener & $\begin{array}{c}\text { Pea } \\
\text { protein }\end{array}$ & $\begin{array}{c}\text { Whey } \\
\text { protein }\end{array}$ & $\begin{array}{c}\text { Milk } \\
\text { protein }\end{array}$ \\
\hline Fructose & $0.551^{\text {de }}$ & $0.652^{\mathrm{a}}$ & $0.592^{\mathrm{abcd}}$ \\
Monk fruit & $0.565^{\text {cde }}$ & $0.646^{\mathrm{a}}$ & $0.545^{\mathrm{de}}$ \\
Stevia & $0.627^{\mathrm{abc}}$ & $0.638^{\mathrm{ab}}$ & $0.577^{\mathrm{bcde}}$ \\
Sucralose & $0.518^{\mathrm{e}}$ & $0.627^{\mathrm{abc}}$ & $0.536^{\mathrm{de}}$ \\
Sucrose & $0.546^{\mathrm{de}}$ & $0.656^{\mathrm{a}}$ & $0.534^{\mathrm{de}}$
\end{tabular}

${ }^{\mathrm{a} e}$ Mean slopes with different letters are significantly different $(P<$ $0.05)$.

${ }^{1}$ Bars were formulated at $15 \mathrm{~g}$ of protein per $62 \mathrm{~g}$ serving and to sweet taste equivalency to a $10 \% \mathrm{wt} / \mathrm{vol}$ sucrose solution.

\section{Descriptive Analysis}

Descriptive analysis documented predominant flavor differences that were due to protein type rather than sweetener differences (Figure 2). Bars made with MP were associated with milky, sweet aromatic, and tortilla

Biplot (axes F1 and F2: $82 \%$ )

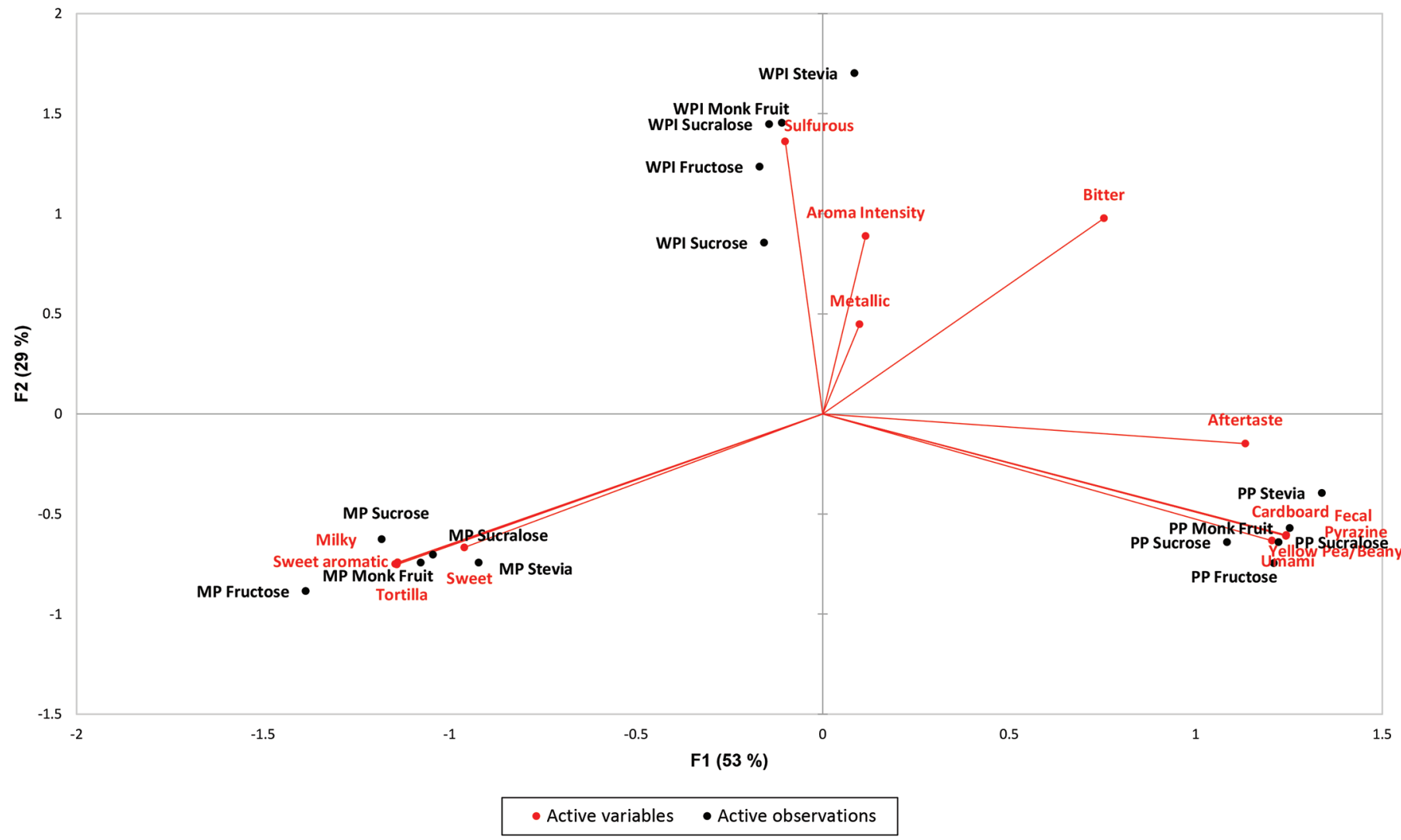

Figure 2. Principal component biplot of sensory flavor profile of protein bars at iso-sweet taste, reported by a trained panel. Bars were formulated at $15 \mathrm{~g}$ of protein per $62 \mathrm{~g}$ serving. $\mathrm{PP}=$ pea protein, $\mathrm{MP}=$ milk protein, $\mathrm{WPI}=$ whey protein isolate. Sweetener is defined. 


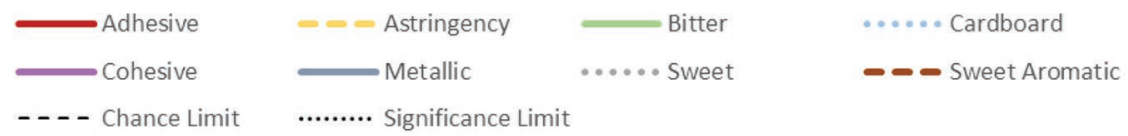

a)

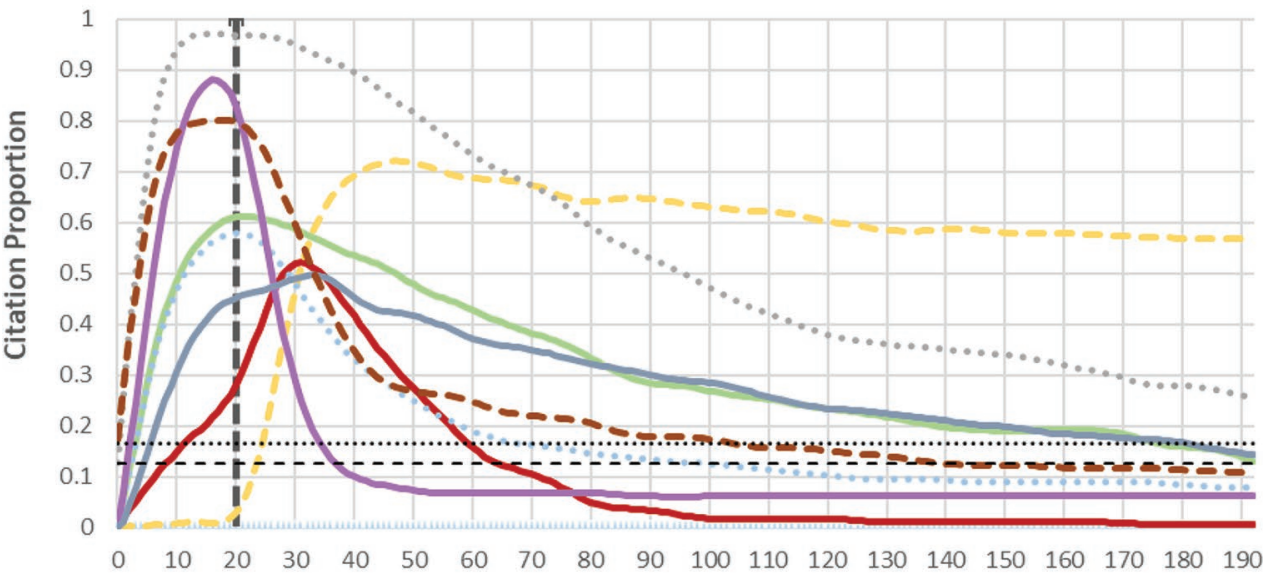

b)

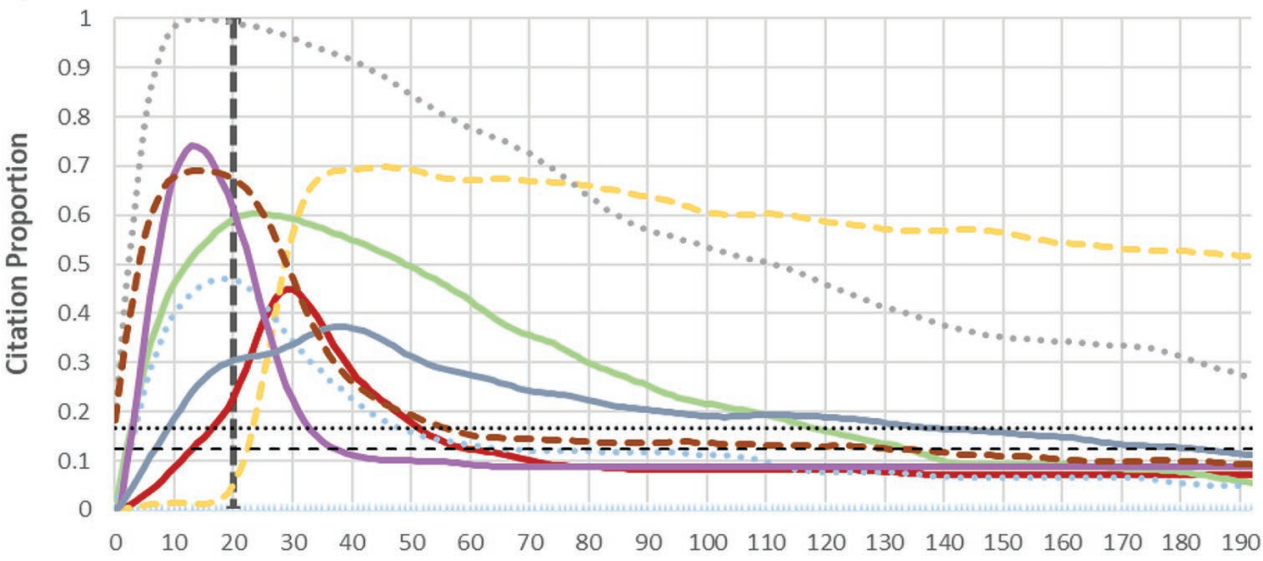

c)

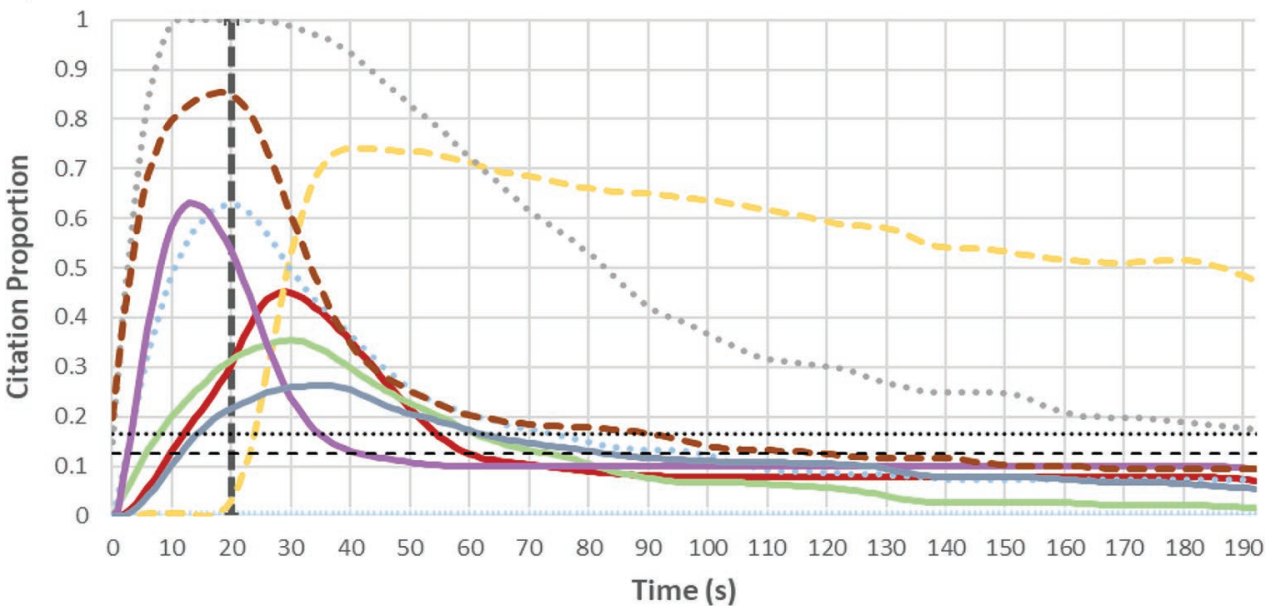

Figure 3. (a) Temporal check-all-that-apply (TCATA) curves for protein bars made with whey protein isolate. (b) TCATA curves for protein bars made with pea protein. (c) TCATA curves for protein bars made with milk protein. For all graphs, vertical lines denote expectoration of sample during evaluation (in-mouth: 0 to $20 \mathrm{~s}$; aftertaste: 20 to $192 \mathrm{~s}$ ). Graphs averaged across sweeteners (sucrose, sucralose, stevia, monk fruit, and fructose) within each protein type. 
a)

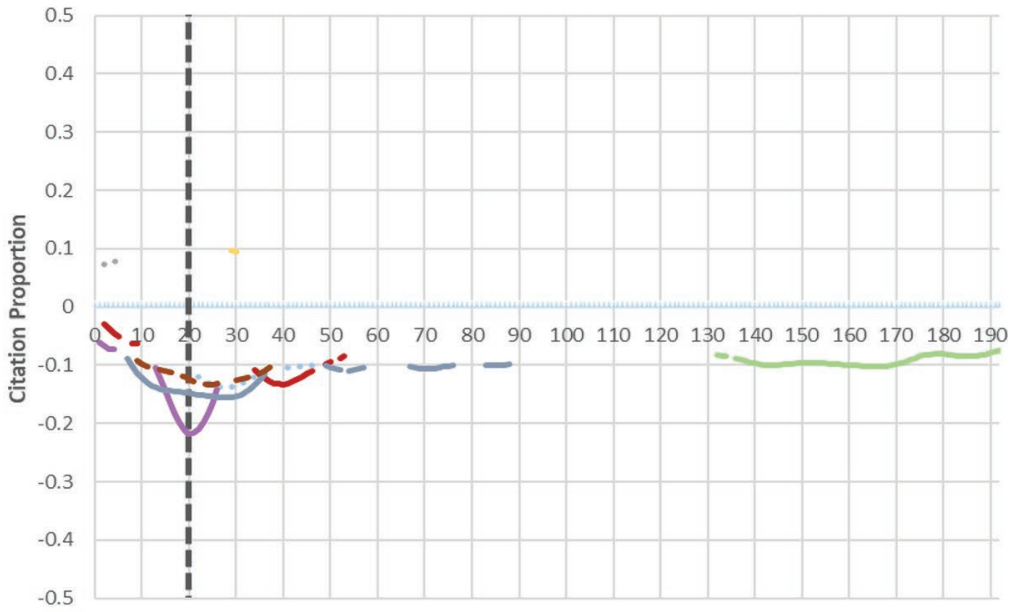

b)

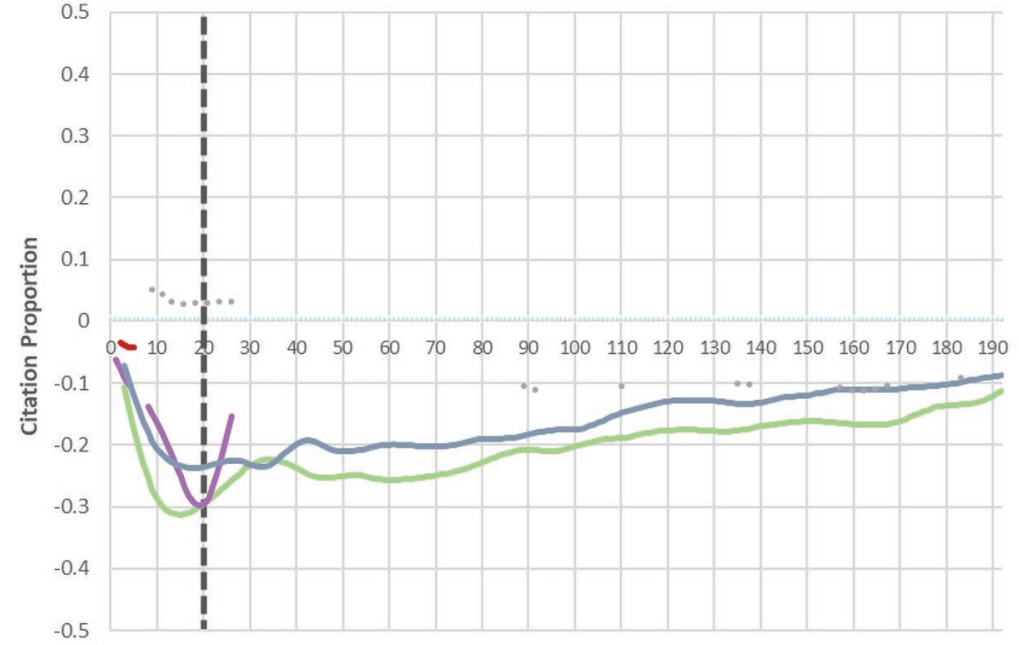

c)

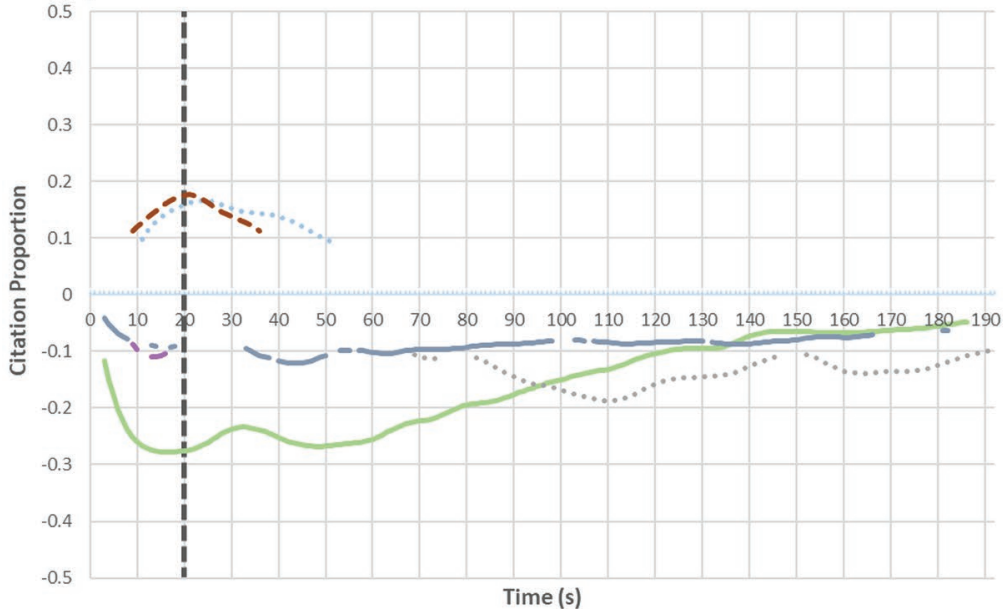

Figure 4. (a) Difference $(P<0.05)$ in temporal check-all-that-apply (TCATA) curves for protein bars made using pea protein versus whey protein. (b) Difference $(P<0.05)$ in TCATA curves for protein bars made using milk protein versus whey protein. $(c)$ Difference $(P<0.05)$ in TCATA curves for protein bars made using milk protein versus pea protein. For all graphs, vertical lines denote expectoration of sample during evaluation (in-mouth: 0 to $20 \mathrm{~s}$; aftertaste: 20 to $192 \mathrm{~s}$ ). Graphs averaged across sweeteners (sucrose, sucralose, stevia, monk fruit, and fructose) within protein type. 
flavors, and sweet taste. Bars made with PP were associated with yellow pea or beany, pyrazine, fecal, and cardboard flavors, and low but distinct umami taste, which was not documented in MP or WPI bars. Bars made with WPI were characterized by cardboard fla- vor (as were PP bars), as well as sulfurous flavor and low bitter taste intensity. These protein-specific and protein-type flavors have been previously documented in protein-based products (Russell et al., 2006; Wright et al., 2009; Smith et al., 2016).

Table 4. $P$-values for the main effects and interaction of protein and sweetener when analyzed within time for protein bar instrumental color ${ }^{1}$ and texture and trained panel sensory texture attributes

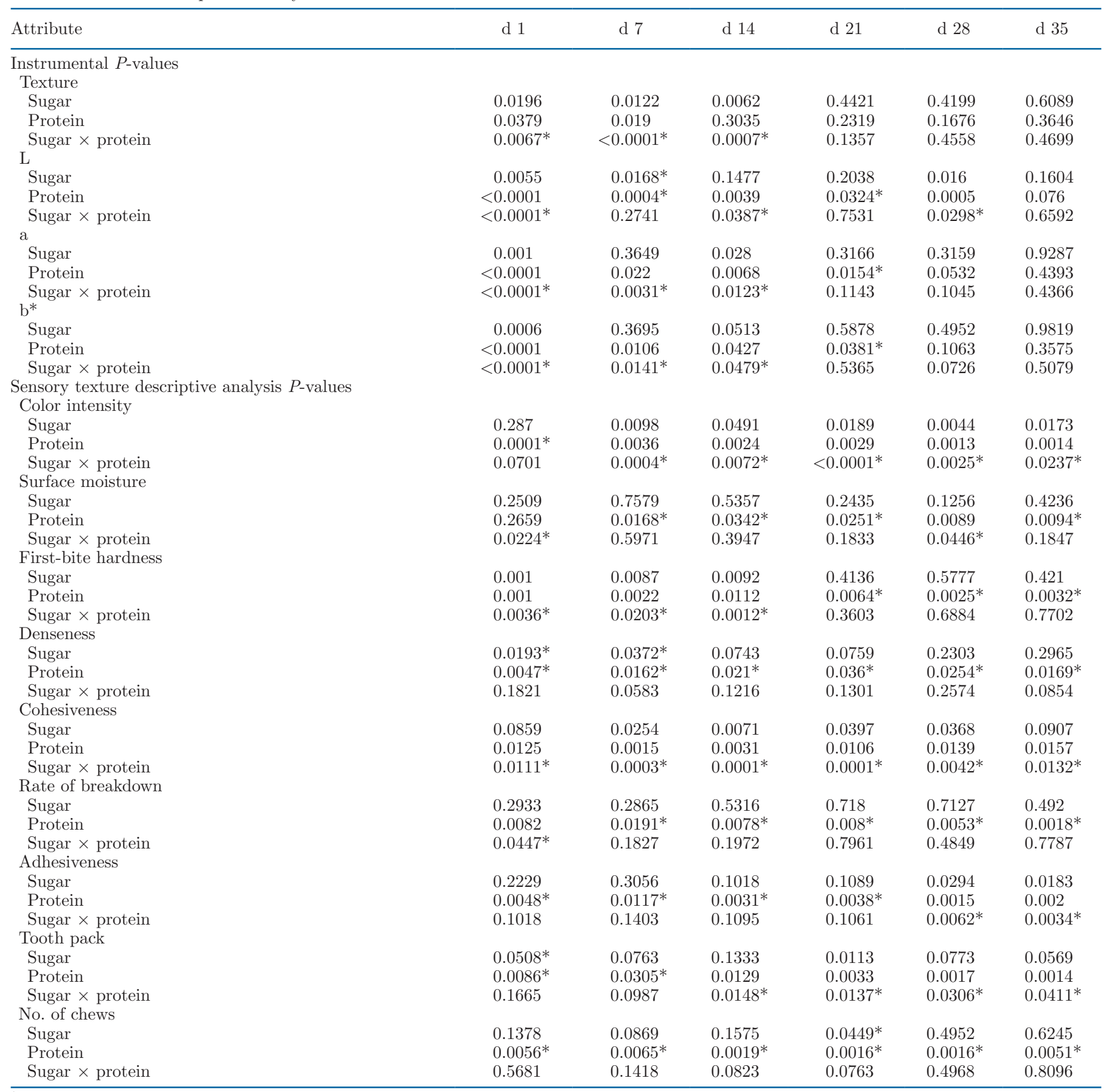

${ }^{1} \mathrm{~L}=$ Hunter luminosity value; $\mathrm{a}=$ Hunter redness value; $\mathrm{b}^{*}=$ Commission Internationale de l'Eclairage (CIE) yellowness value.

${ }^{*}$ Cells with asterisks indicate significant effects and interactions $(P<0.05)$. 


\section{Temporal Check All That Apply}

Temporal effects of sweetener type and protein were investigated from the TCATA results. When averaged across the 3 protein types, distinct temporal differences among the sweeteners were documented $(P<0.05)$, similar to results reported by Parker et al. (2018) for ready-to-mix protein beverages (results not shown). Bitter and metallic taste was documented in bars made with monk fruit, sucralose, and stevia. Sweet aromatic, cardboard, and sweet taste were present in all protein bars with similar time onsets. Distinct temporal differences were also documented among the different protein types (Figure 1). Bars made with WPI were highly cohesive, had the highest metallic citation proportion, and were the only protein type in which sweet taste did not go to $100 \%$ citation proportion (Figure 3a). Bars made with PP and WPI had higher bitter citation proportions compared with MP (Figure 3). Bars made with MP had the highest sweet aromatic frequency (Figure 3c). All 3 protein bar types had a lingering astringency (Figure 3).

Significant temporal differences between the protein sources are shown in Figure 2. In-mouth and just after expectoration, WPI bars were higher than PP bars in sweet aromatic taste, cohesiveness, metallic taste, sweet taste, and adhesiveness (Figure 4a; $P<0.05$ ). Ninety seconds after expectoration, WPI bars were more bitter than PP bars (Figure 4a; $P<0.05$ ). In-mouth and after expectoration, WPI bars were more cohesive, metallic, and bitter than MP bars (Figure 4b). Bars made with MP were higher in sweet taste than were WPI bars (Figure $4 \mathrm{~b} ; P<0.05$ ). Comparing MP bars with PP bars, MP bars were higher in sweet aromatic and cardboard flavors, whereas PP bars were more cohesive, bitter, and metallic (Figure 4c). Post-expectoration, PP bars were higher in bitter, metallic, and sweet taste compared with MP bars (Figure 4c; $P<0.05$ ).

\section{Bar Hardening}

Protein source and sweetener had significant interactions or significant main effects for instrumental and sensory visual and textural properties across all attributes $(P<0.05$; Table 4$)$. Bar hardening was seen in all bars regardless of protein type and sweetener source (Figure 5). Bar hardening in protein bars is proposed to be caused by protein aggregation from disulfide linkage

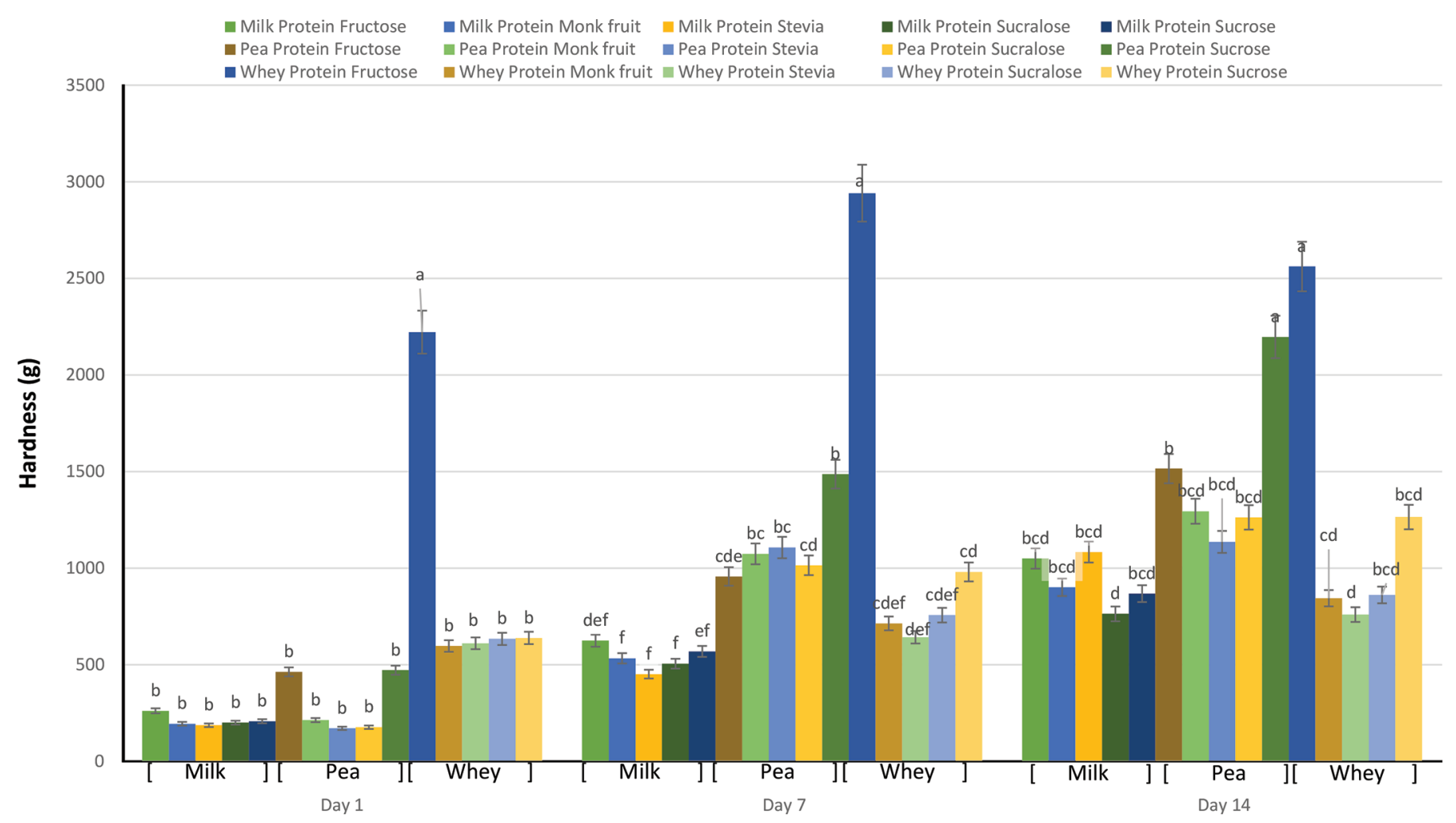

Figure 5. Instrumental hardness for protein bars separated by protein and sweetener within each storage time point. Protein bars with different letters within the same time point are significantly different $(P<0.05)$. Standard error bars are included. Bars were stored at $35^{\circ} \mathrm{C}$. 


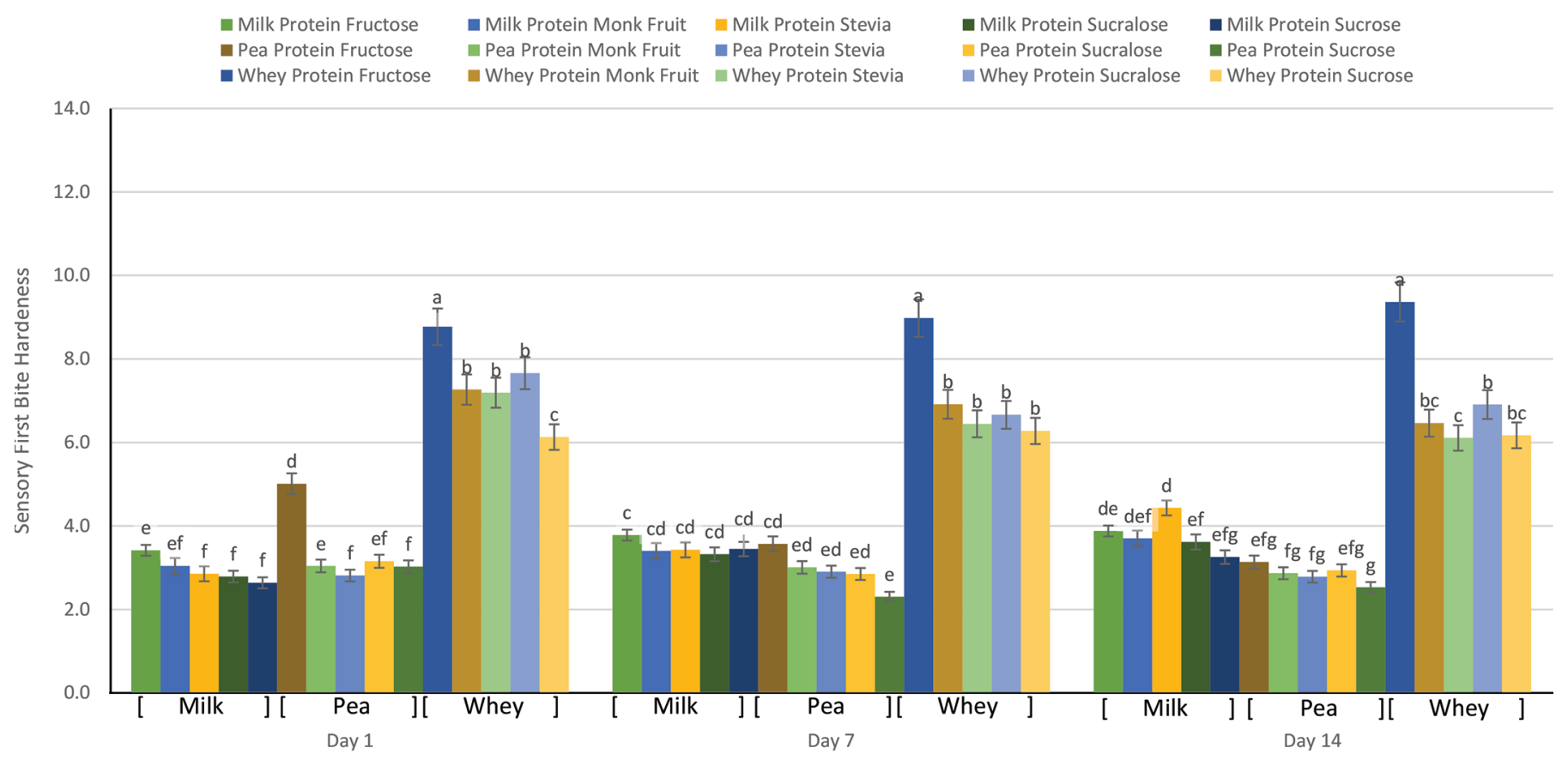

Figure 6. Sensory first-bite hardness for protein bars, separated by protein and sweetener within each time point. Sensory first-bite hardness was scored by a trained panel on a 0 - to 15-point product-specific intensity scale (Meilgaard et al., 2016), where $1=$ very low intensity and 15 $=$ very high intensity. Protein bars with different letters within the same time point are significantly different $(P<0.05)$. Standard error bars are included. Bars were stored at $35^{\circ} \mathrm{C}$.

formation, non-covalent interactions, and the Maillard reaction with reducing sugars (McMahon et al., 2009; Liu et al., 2011; Zhou et al., 2013). In this study, WPI bars made with fructose were consistently the hardest (Figure 5). Other bars, such as PP made with sucrose, had an upward trend of instrumental hardening to a

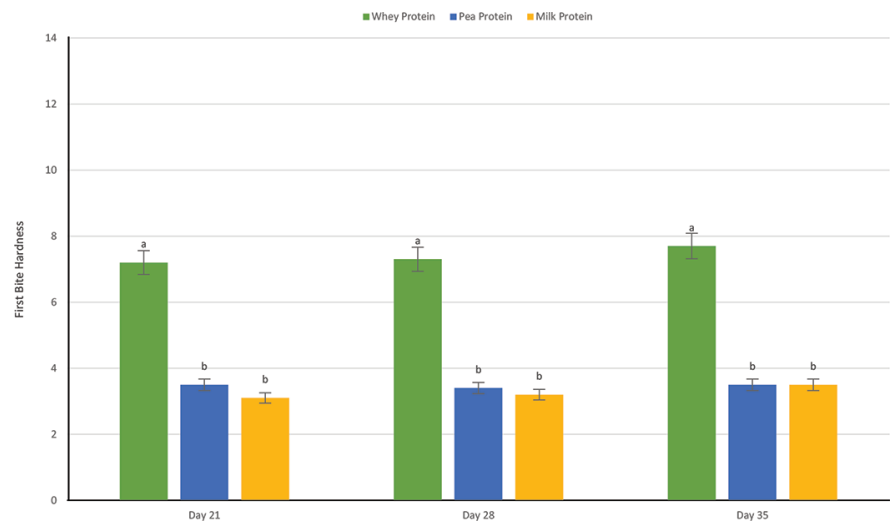

Figure 7. Protein type main effects for sensory first bite for protein bars. First-bite hardness was scored by a trained panel on a 0to 15-point product-specific intensity scale (Meilgaard et al., 2016), where $1=$ very low intensity and $15=$ very high intensity. Protein bars with different letters within the same time point are significantly different $(P<0.05)$. Standard error bars are included. Bars were stored at $35^{\circ} \mathrm{C}$. greater degree than did WPI bars at $\mathrm{d} 7$ and 14 (Figure 5). At d 21, no differences in instrumental bar hardening were discovered $(P>0.05$; results not shown).

Sensory first-bite hardness confirmed that WPI bars made with fructose were the hardest for the first 3 time points, consistent with instrumental hardness (Figure 5). At d 1 and 7, all protein bars made with fructose were harder and denser than bars with other sweeteners (Figure 6, 7, and 8b). By d 21 to 35, we found a protein main effect, and WPI bars required more first-bite force did than PP or MP bars. Additionally, WPI bars were denser than $\mathrm{PP}$ and MP bars at all time points (Figure 8a). In terms of cohesiveness, a significant interaction occurred between sweetener and protein type at all time points $(P<0.05)$. Bars made with WPI were consistently the most cohesive, and PP bars were the least cohesive (Figure 9). All sweeteners had a significant effect on cohesiveness at all time points. Bars made with PP were the driest, whereas WPI bars had the highest surface moisture at all time points and appeared moist throughout the study (Figure 10). Finally, PP and MP bars had a faster rate of breakdown than WPI bars at all time points, with the exception of d 1 (Figure 11).

Instrumental and sensory color differences were also documented. Bars made with WPI had the greatest instrumental change in color compared with PP or MP, but all protein bar formulas visibly darkened and in- 
creased in yellow or red color over time (Figure 12; $P<$ 0.05). In terms of sensory visual effects, an interaction occurred between sweetener and protein type (Table 4). All bars had visible color changes by sensory and instrumental measurements, but bars with fructose displayed the largest changes in color across storage $(P$ $<0.05)$.

A principal component biplot of the protein bars across storage time provides a visual assessment of differences among the different bars (Figure 13). Principal component 1 (PC1; 54\%) was positively associated with sensory first-bite hardness, sensory denseness, sensory cohesiveness, sensory adhesiveness, sensory tooth pack, and sensory number of chews, and negatively associated with sensory rate of breakdown. Bars made with WPI were positively associated with PC1, whereas MP and PP bars were negatively associated with PC1. Bars made with WPI were initially the hardest but hardened at a slower rate than MP and PP bars. Bars made with WPI were hard, cohesive, dense bars, with high tooth
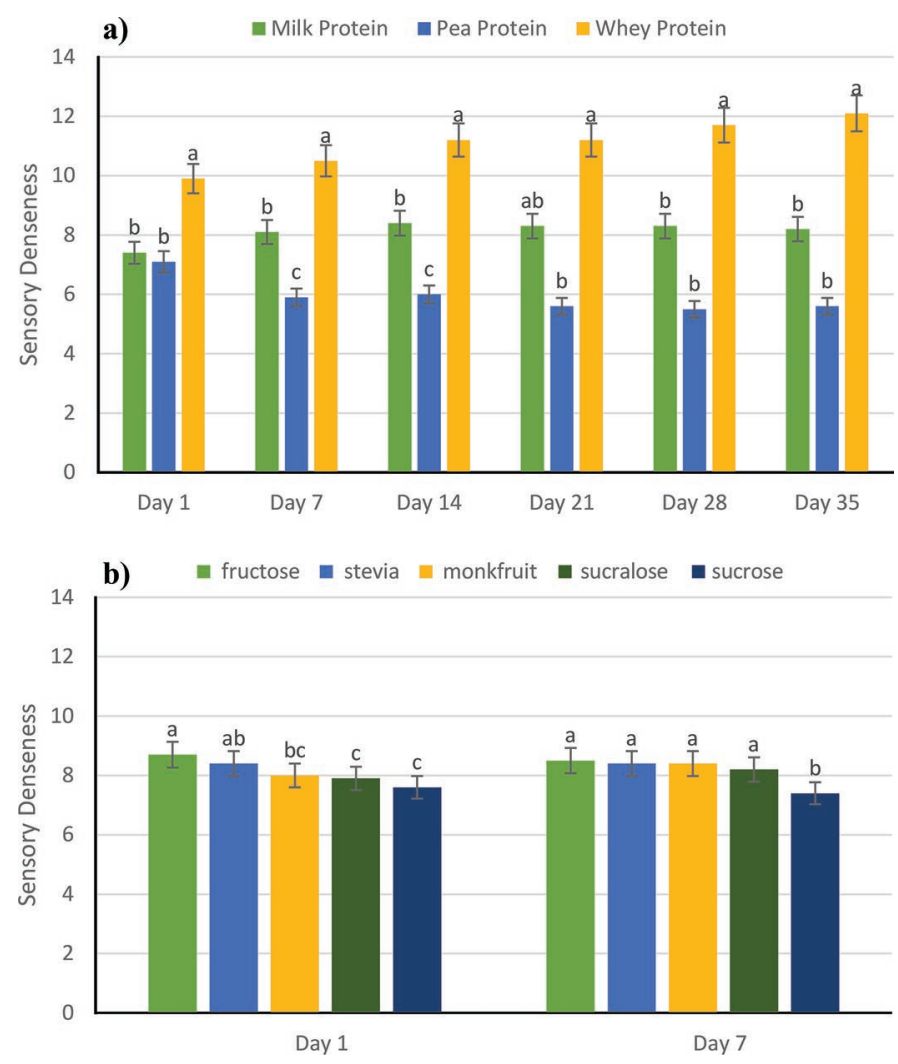

Figure 8. (a) Protein type main effects and (b) sugar main effects for sensory denseness for protein bars. Sensory denseness was scored by a trained panel on a 0 - to 15 -point product-specific intensity scale (Meilgaard et al., 2016), where $1=$ very low intensity and $15=$ very high intensity. Protein bars with different letters within the same time point are significantly different $(P<0.05)$. Standard error bars are included. Bars were stored at $35^{\circ} \mathrm{C}$. packing, whereas MP and PP bars were lower in these attributes and had faster rates of breakdown. Principal component 2 (PC2; 26\%) was positively associated with sensory surface moisture and Hunter L, and negatively associated with sensory color intensity, Hunter a, and CIE b*. Day 1 time points for MP and WPI bars were positively associated with $\mathrm{PC} 2$, whereas $\mathrm{PP}$ bars were negatively associated with $\mathrm{PC} 2$ at all time points, as PP bars started and remained more brown throughout the study compared with bars of other protein types.

Principal component analysis biplots of each protein type across sweetener and time point were also generated to visualize differences within each protein type (Figure 14). For MP bars, PC1 (52\%) was positively associated with sensory surface moisture, sensory adhesiveness, Hunter L, and sensory tooth packing, and negatively associated with sensory denseness, sensory color intensity, sensory number of chews, instrumental texture, Hunter a, and CIE b*. Principal component 2 (14\%) was positively associated with sensory first-bite hardness and sensory cohesiveness. At d 1, bars loaded positively with $\mathrm{PC} 1$, whereas at $\mathrm{d} 7$ and 14, bars loaded positively with $\mathrm{PC} 2$. Bars made with MP at $\mathrm{d} 1$ were light in color, moist, and not very cohesive. As bars aged from d 1 to d 14, MP bars became harder, drier, darker, and more cohesive.

For PP bars, PC1 (48\%) was positively associated with color intensity, instrumental texture, CIE b*, and Hunter a, and negatively associated with surface moisture, sensory denseness, sensory cohesiveness, sensory adhesiveness, and sensory tooth pack. Principal component $2(17 \%)$ was positively associated with sensory first-bite hardness and sensory number of chews, and negatively associated with sensory rate of breakdown. Bars at d 21 to 35 were positively associated with PC1, and as the bars aged, PP bars became harder (measured instrumentally), less dense, and darker in color.

For WPI bars, PC1 (57\%) was positively correlated with sensory color intensity, sensory denseness, sensory cohesiveness, and Hunter L, and negatively associated with sensory surface moisture, sensory rate of breakdown, sensory adhesiveness, sensory tooth pack, sensory number of chews, Hunter a, and CIE b*(Figure 14c). Day 21 to 35 WPI bars loaded positively for PC1, whereas d 1 WPI bars loaded negatively on PC1. After d 1, we discovered no consistent trend with time, suggesting that another factor besides sweetener source and time affected WPI bar hardening after $\mathrm{d} 1$. Principal component $2(19 \%)$ was positively associated with sensory first-bite hardness and instrumental texture. Principal component 2 loaded most positively with the fructose WPI bars, and these bars were consistently the hardest WPI bars. 


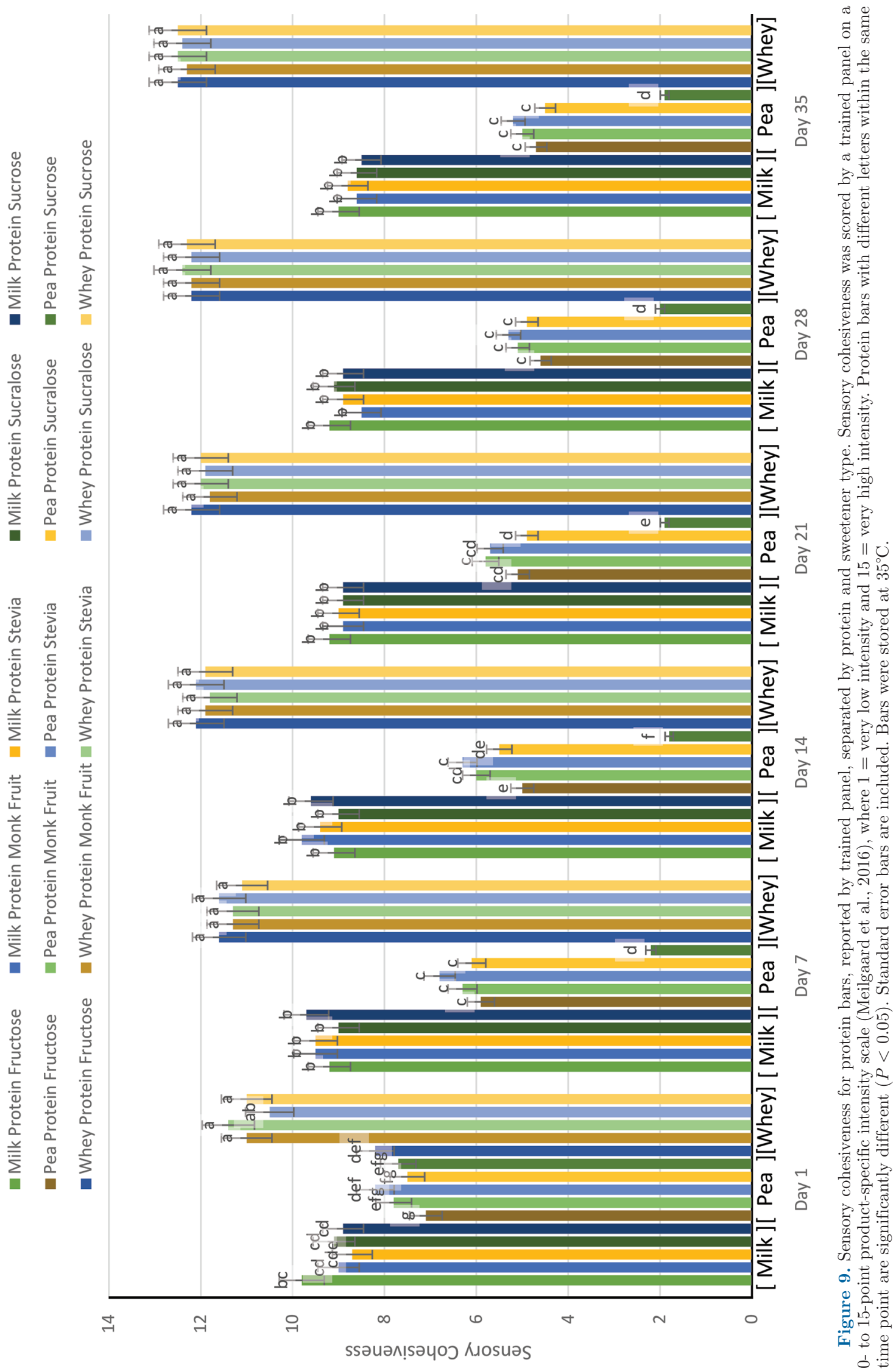




\section{DISCUSSION}

Bars made with WPI and PP required significantly more sweetener than MP bars for an iso-sweet taste intensity within the same sweetener. Additionally, WPI and PP had a slightly higher protein content that could have contributed to this difference. Most likely, the bitter taste of WPI and PP are the reason that these bars required additional sweetener to reach iso-sweetness (Liu et al., 2014; Zeeb et al., 2018). It is important to note, for sugar reduction efforts, that within a single specific formulation it cannot be assumed that changing the protein type does not change the iso-sweet taste. Additionally, results from this study suggest that, alone, the specific stevia used in this study is not a suitable sugar substitute in protein bars made with WPI or PP, due to increased bitterness from the stevia in addition to that from the proteins, which would most likely result in consumer rejection. However, monk fruit or sucralose could be used for sugar reduction or replacement in WPI or PP protein bars without a large increase in bitterness. Previous work has determined that consumers desire "naturally sweetened" and "lowcarbohydrate" product claims, but many consumers are flavor-driven and will choose taste over product claims (Li et al., 2015; Oltman et al., 2015; Parker et al., 2018). Future work should evaluate different stevia sources with reported lower bitter levels, investigate sweetener blends to decrease bitterness, and determine consumer acceptance of the protein bars (Parker et al., 2018).

The results from TCATA additionally suggest a temporal effect of protein and sweetener types that affected bitter, sweet, and metallic tastes across all bars. This effect could have been caused by 2 possible factors. The
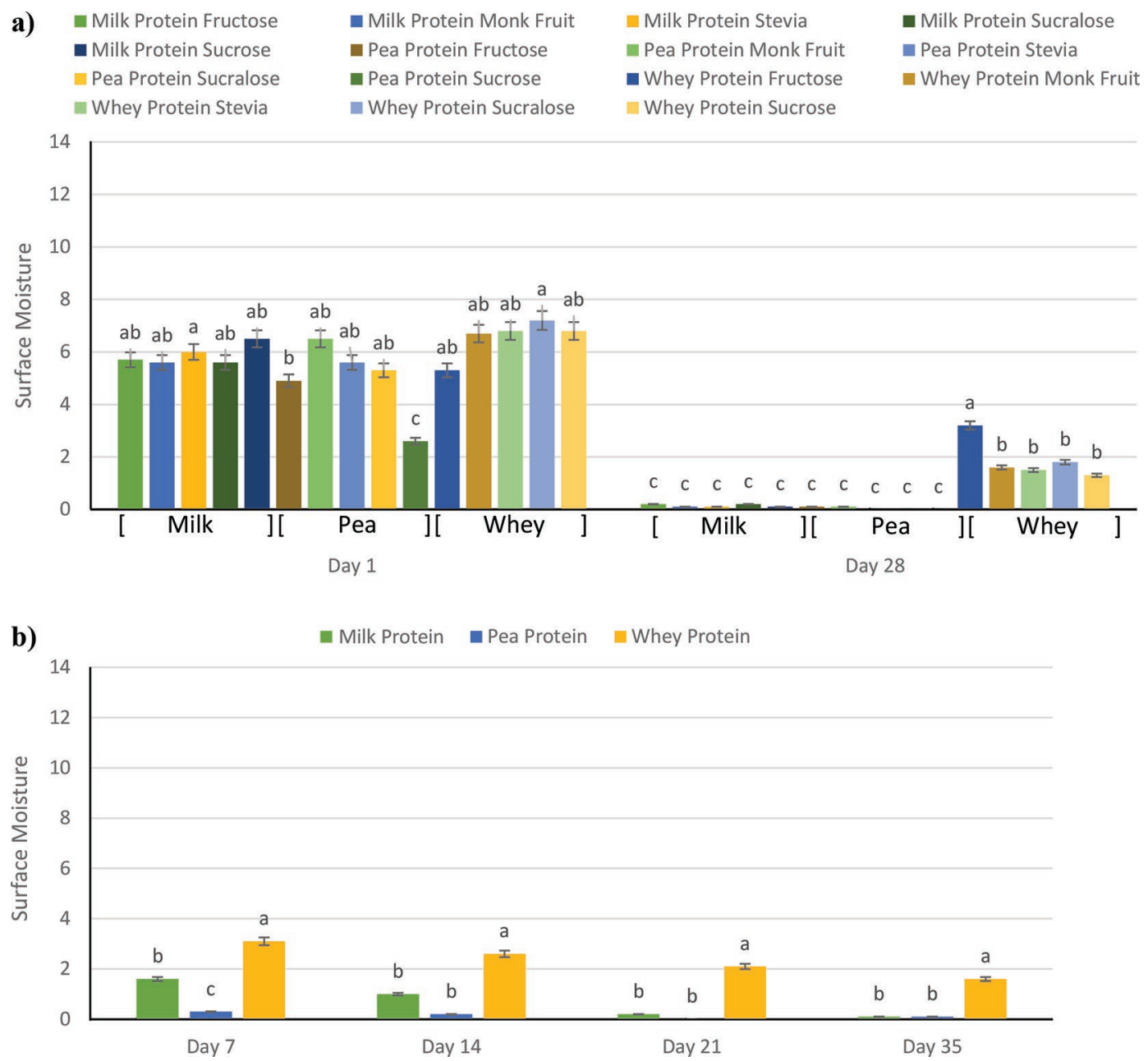

Figure 10. (a) Sensory surface moisture for protein bars, reported by trained panel, separated by protein and sweetener type. (b) Sensory surface moisture protein type main effects. Sensory surface moisture was scored by a trained panel on a 0- to 15-point product-specific intensity scale (Meilgaard et al., 2016), where $1=$ very low intensity and $15=$ very high intensity. Protein bars with different letters within the same time point are significantly different $(P<0.05)$. Standard error bars are included. Bars were stored at $35^{\circ} \mathrm{C}$. 
first could be due to possible interactions between adhesiveness or tooth packing and the lingering tastes. Bar hardening data demonstrated a significant effect of all protein and sweetener sources at d 1 for sensory tooth packing and could have led to temporal differences in bitter, sweet, and metallic tastes across all bars. Bars made with WPI had significantly higher tooth packing than PP bars and MP bars at d 1, which could have led to temporal differences seen in TCATA frequencies (Table 4). The second possibility could be an interaction between the protein and sweetener types. The interaction could have led to different binding affinities or delays in sweetener binding due to structural interactions causing different temporalities (Acevedo et al., 2018). Both possibilities would result in the temporal differences in bitter, metallic, and sweet tastes seen in this study. In contrast, when mixtures of whey proteins and sweeteners are consumed as a liquid, no differences were observed (Parker et al., 2018).

All bars experienced differences in hardening across the study, which would lead to differences in shelf life. For high-protein bars, the minimum shelf life is $6 \mathrm{mo}$, but producers often desire a shelf life of more than 12 mo (Banach et al., 2014). Imtiaz et al. (2012) previously reported that protein type influences bar firmness, and a high-protein bar typically contains around 20 to $50 \%$ protein (12.4 to $31 \mathrm{~g}$ of protein in a $62-\mathrm{g}$ bar). Bars with WPI, although initially harder than all other proteins, equalized over time but were consistently denser at all time points than PP bars or MP bars (Figure 3 and 8a). Imtiaz et al. (2012) reported that high-protein bars made with MP developed a crumbly texture over time and lacked cohesion. Consistent with previous studies, crumbliness increased in bars made with MP and PP (Li et al., 2008; Imtiaz et al., 2012). Bars made with MP and PP load close together on the principal component biplot (Figure 13), suggesting that the 2 proteins behaved similarly in the accelerated shelf life testing. In this study, bars made with PP were the driest (Figure 11) and least cohesive (Figure 10) and had the fastest rate of breakdown across shelf life (Figure 12; $P$ $<0.05$ ), and bars made with MP had a lower density, which was noted to cause a crumbly texture (Figure 8a; Beck et al., 2017).

Regarding effect of sweeteners, WPI bars made with fructose were harder than other bars until d 21 (Figure $3)$. Bars with whey protein stored extra water within the matrix (water activity 0.619), and because fructose is an extremely hygroscopic molecule, over time the whey protein matrix released the extra water present (Davis, 1995; Hobbs, 2019). Over time, fructose in the bar can slowly absorb the trapped water from the whey protein matrix, and by d 14 of this study, the fructose had absorbed enough water to form a visible fructose syrup (Hobbs, 2019). This syrup could have caused softening after d 14, and by d 21 the difference between the WPI bars made with fructose and all other bars may have been minimized due to the hygroscopic nature of fructose. Ultimately, the hygroscopic nature of fructose may have led to no significant interactions between sweetener and protein source in terms of texture and first-bite hardness after d 14, possibly mitigating bar hardening due to moisture migration (Table 4; McMahon et al., 2009). The non-nutritive sweetener bars, with slightly higher fiber contents to maintain equivalent protein content, were less hard than their nutritive-sweetener counterparts (fructose and sucrose) until the 6-mo shelf life equivalent. This study demonstrates that non-nutritive sweeteners do not have a negative effect on bar hardness in low-carbohydrate, high-protein bars and would not negatively affect the shelf life of the bars.

All protein bars exhibited color changes throughout the study, but WPI bars demonstrated the most notable change, beginning at $\mathrm{d} 7$. This change in color occurred due to increased Maillard browning compounds caused by the accelerated shelf life conditions (McMahon et al., 2009). In general, the protein-sweetener combinations evaluated resulted in protein bars that darkened in color over time (Figure 9). Future work should address consumer testing with protein bars to confirm acceptable sensory properties and the use of other proteins or protein blends with non-nutritive sweeteners (Loveday et al., 2010; Hogan et al., 2012; Banach et al., 2014).

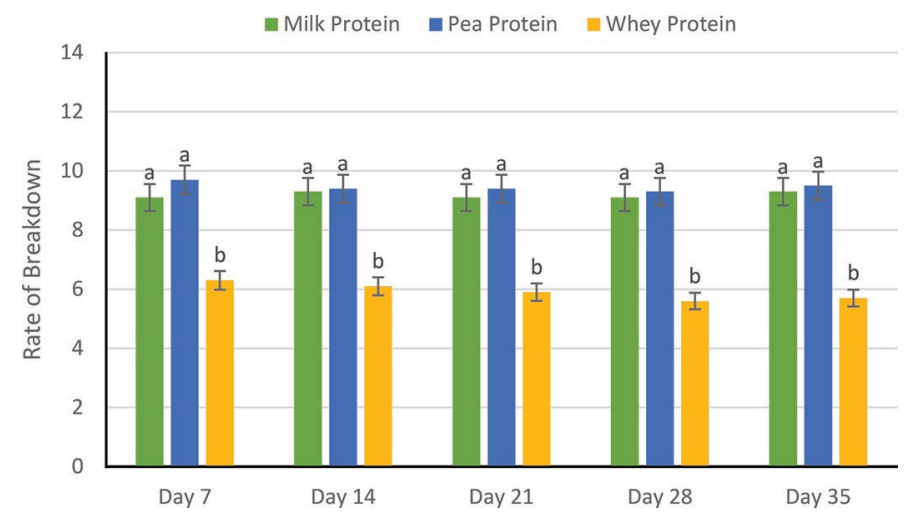

Figure 11. Sensory rate of breakdown intensities for protein bars, reported by trained panel, separated by protein main effects. Sensory rate of breakdown was scored by a trained panel on a 0 - to 15-point product-specific intensity scale (Meilgaard et al., 2016), where $1=$ very low rate of breakdown and $15=$ very high rate of breakdown. Protein types with different letters within the same time point are significantly different $(P<0.05)$. Standard error bars are included. Bars were stored at $35^{\circ} \mathrm{C}$. 
Milk Protein Fructose

- Milk Protein Sucrose

- Pea Protein Sucralose

Whey Protein Stevia
- Milk Protein Monk Fruit

- Pea Protein Fructose

- Pea Protein Sucrose

Whey Protein Sucralose
Milk Protein Stevia

- Pea Protein Monk Fruit

- Whey Protein Fructose

Whey Protein Sucrose milk Protein Sucralose

- Pea Protein Stevia

Whey Protein Monk Fruit

a)

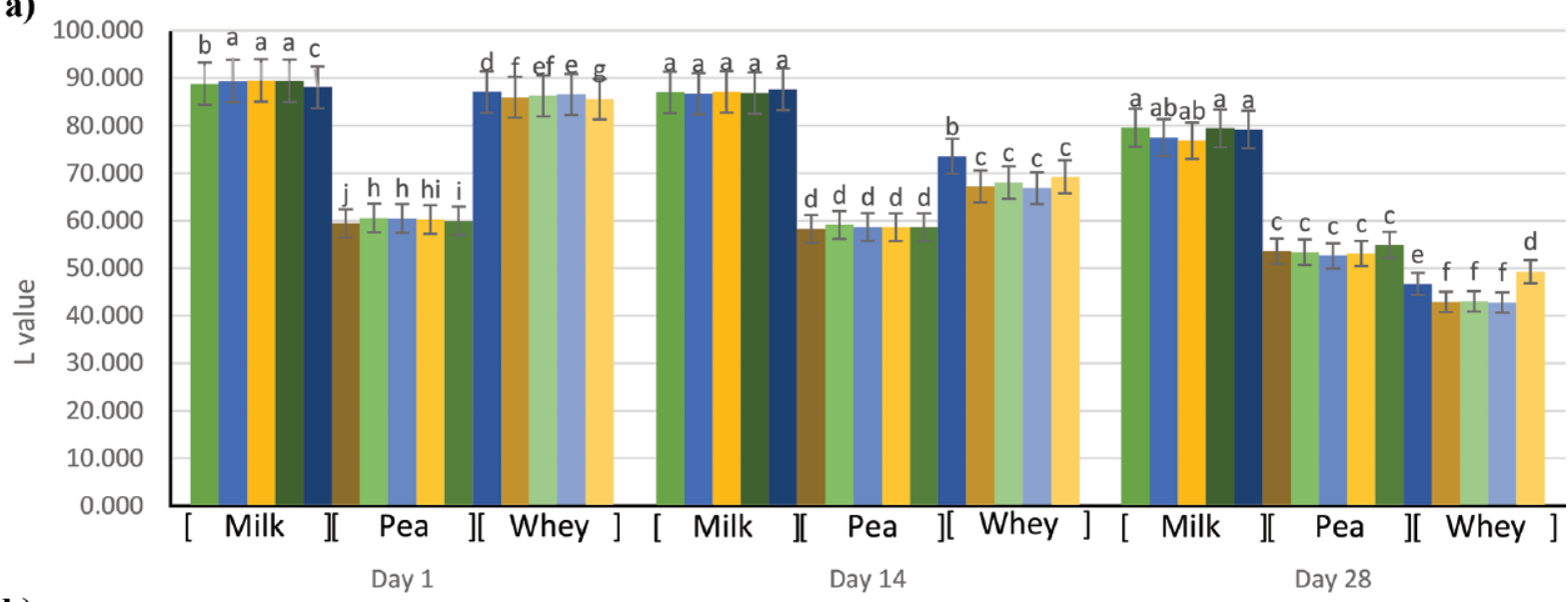

b)

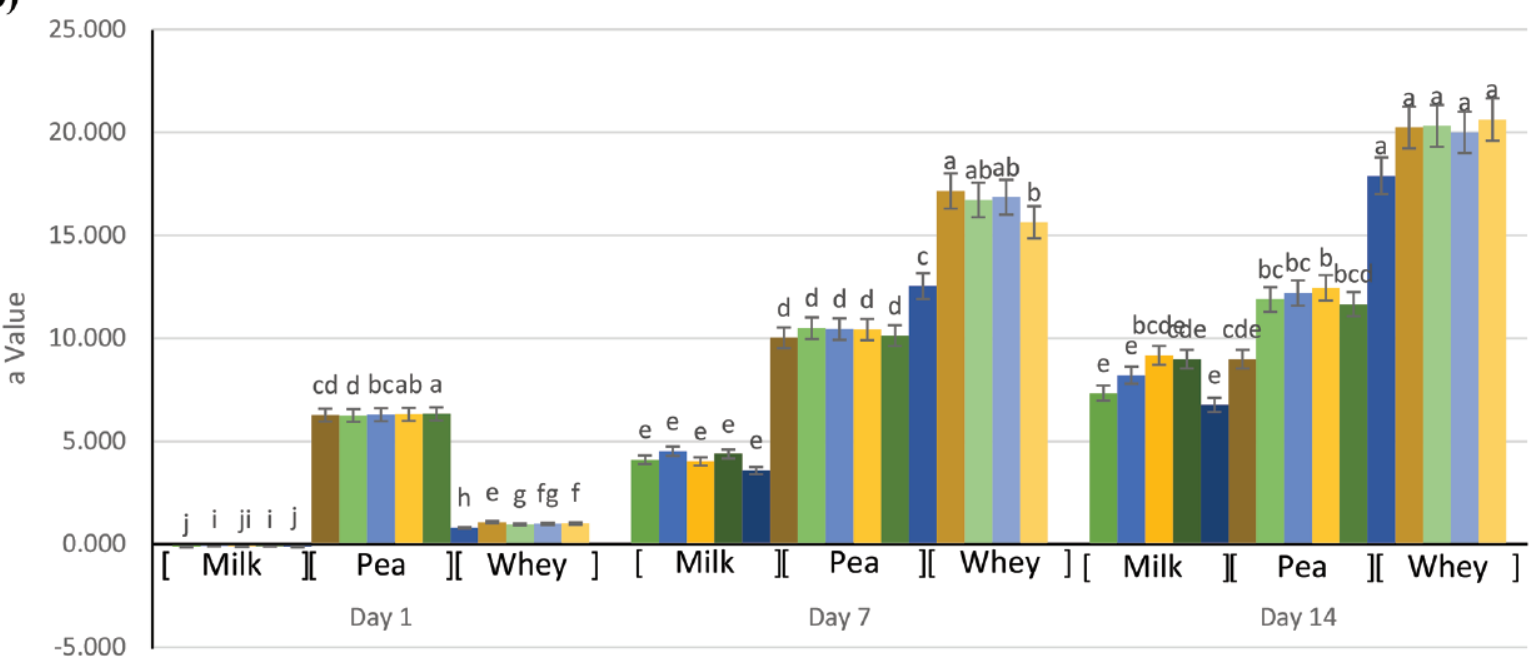

c)

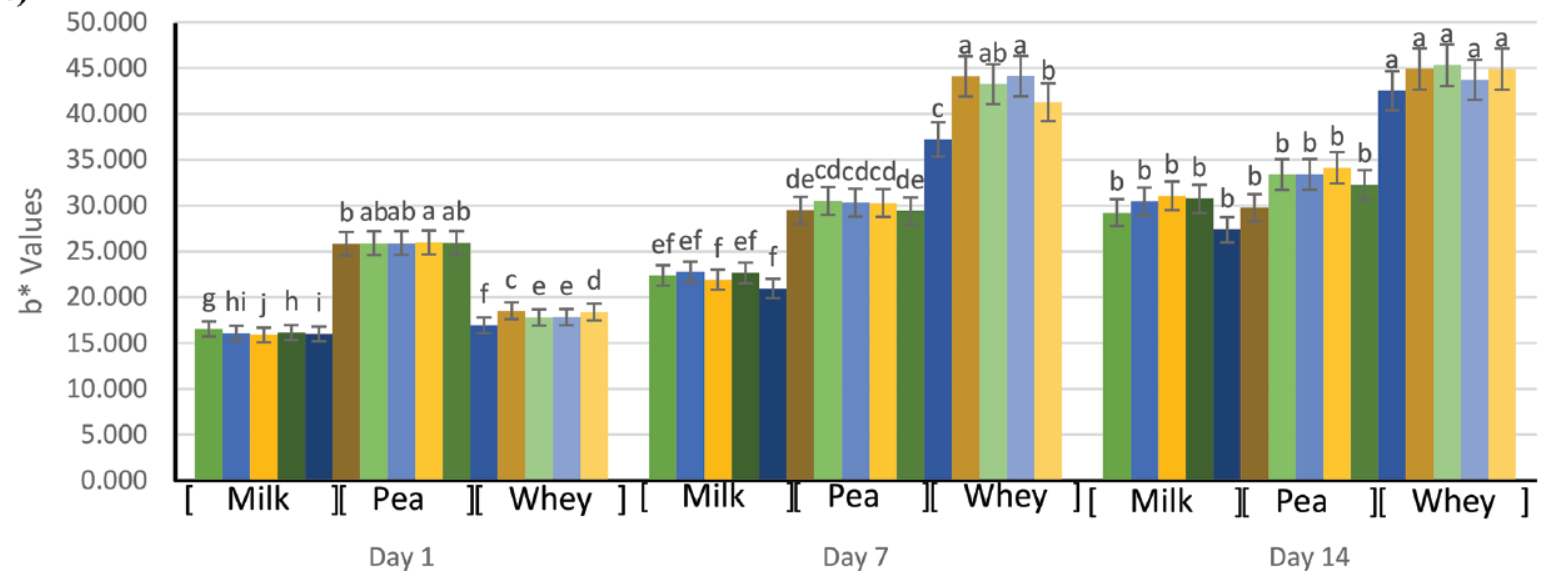

Figure 12. Instrumental color measurements for protein bars at a viewer angle of $10^{\circ}$, separated by protein type and sweetener. (a) Hunter luminosity (L) values, degree of lightness from dark (0) to light (100). (b) Hunter a values, degree of redness $(+)$ or greenness $(-)$. (c) Commission Internationale de l'Eclairage (CIE) $b^{*}$ values, degree of yellowness $(+)$ or blueness $(-)$. Protein bars with different letters within the same time point are significantly different $(P<0.05)$. Bars were stored at $35^{\circ} \mathrm{C}$. 


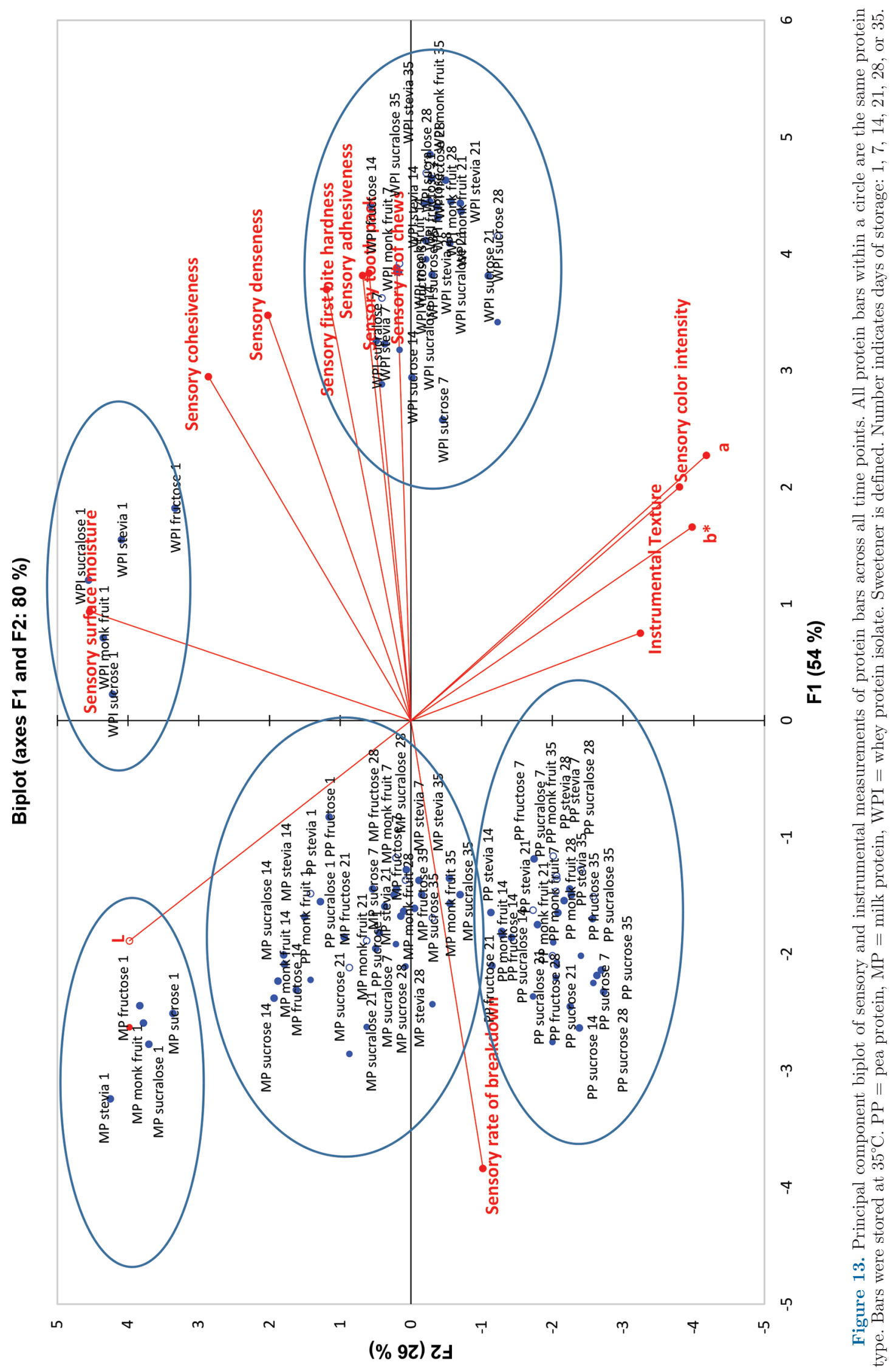


a)

Biplot (axes F1 and F2: $66 \%$ )

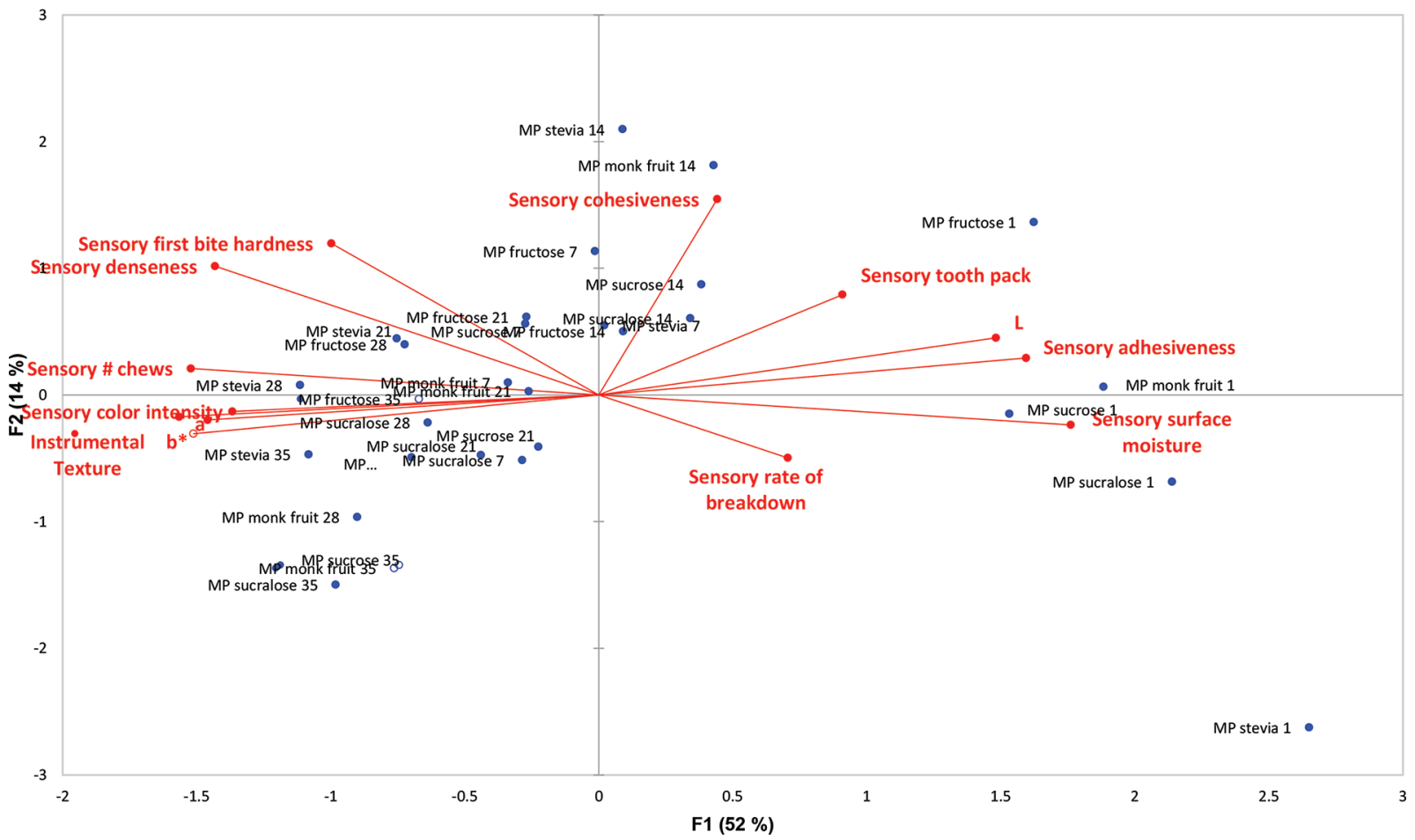

b)

Biplot (axes F1 and F2: $65 \%$ )

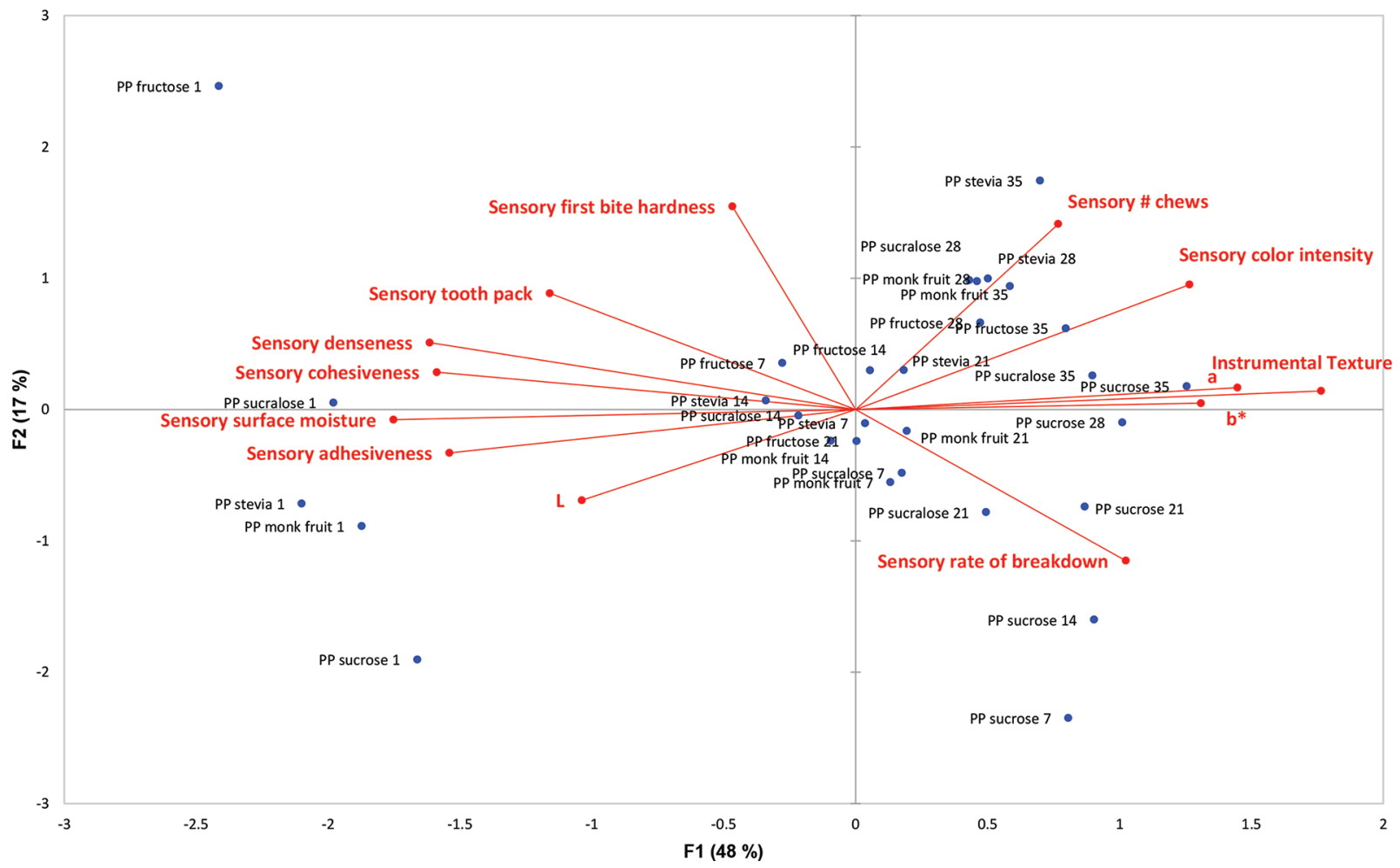

Figure 14. Principal component biplots of sensory and instrumental measurements of (a) milk protein (MP), (b) pea protein (PP), and (c) whey protein isolate (WPI) protein bars across all time points. Bars were stored at $35^{\circ} \mathrm{C}$. Sweetener is defined. Number indicates days of storage: $1,7,14,21,28$, or 35 . 
c)

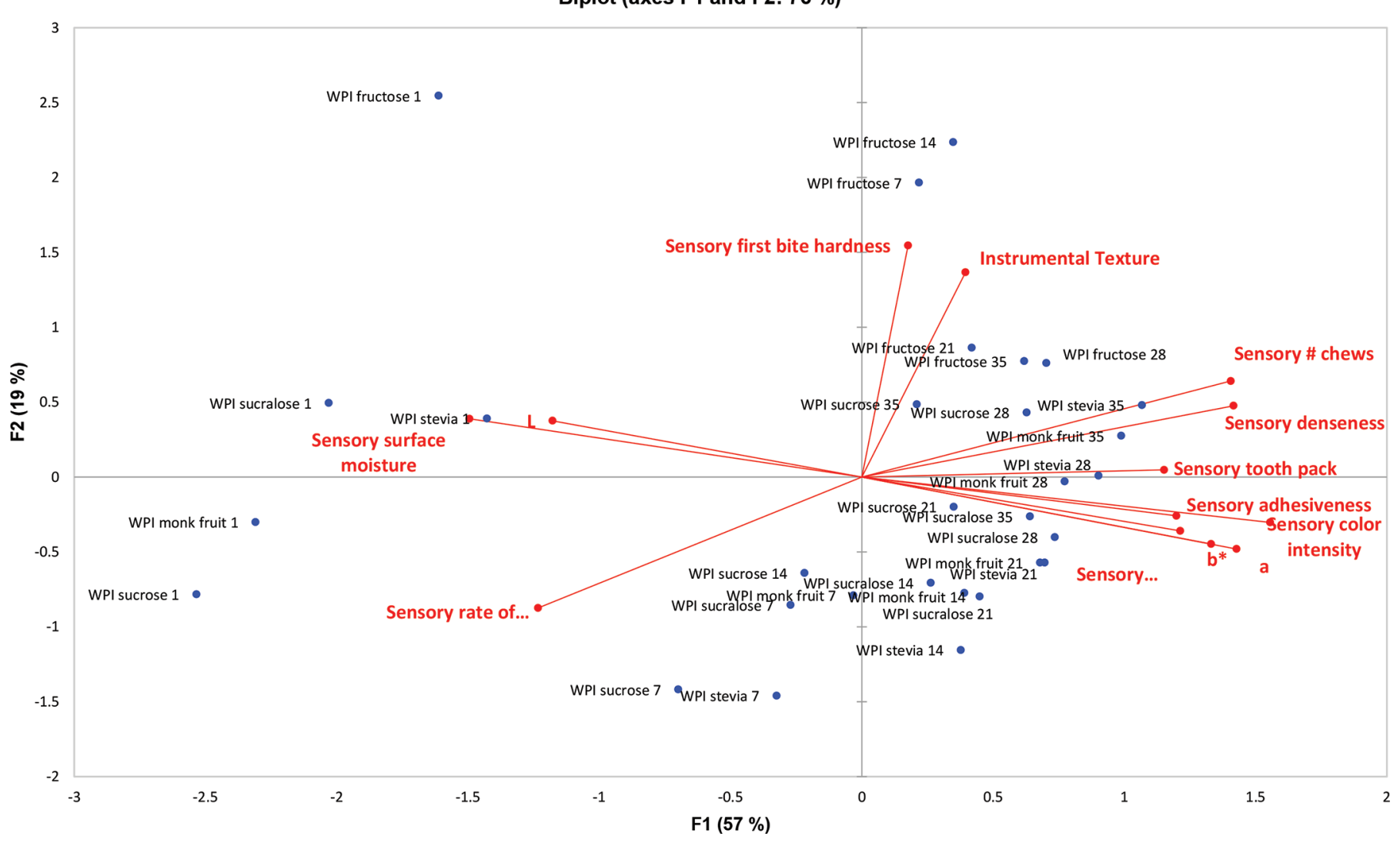

Figure 14 (Continued). Principal component biplots of sensory and instrumental measurements of (a) milk protein (MP), (b) pea protein (PP), and (c) whey protein isolate (WPI) protein bars across all time points. Bars were stored at $35^{\circ} \mathrm{C}$. Sweetener is defined. Number indicates days of storage: $1,7,14,21,28$, or 35 .

\section{CONCLUSIONS}

Based on the results of this study, the type of sweetener and the type of protein used for a protein bar affect bar flavor and texture characteristics and should be chosen carefully. This is important to understand and predict how sugar reduction or sweetener replacement will affect the sensory and textural properties of protein bars within different protein types. Bars made with PP and WPI both required more sweetener than did MP bars to reach iso-sweetness. Flavor differences in protein bars were predominantly due to protein type rather than sweeteners. There was a temporal effect of protein and sweetener types that affected bitter, sweet, and metallic tastes across all bars. Bar hardening (instrumental and sensory first bite) differences caused by sweetener and protein type were evident until d 21 at $35^{\circ} \mathrm{C}, 55 \%$ relative humidity. Bars made with WPI were consistently denser at all time points than PP bars or MP bars, and although initially harder than other protein bars, WPI bars were not different in hardness after d 14. Bars made with PP became dryer and less cohesive over time and would benefit from another protein type incorporated into the bar to increase shelf life. The findings from this study may be useful to protein bar manufacturers.

\section{ACKNOWLEDGMENTS}

Funding was provided in part by Dairy West (Meridian ID), Glanbia Nutritionals (Twin Falls, ID), and the National Dairy Council (Rosemont, IL). The authors confirm there are no conflicts of interest.

\section{REFERENCES}

Acevedo, W., C. A. Ramírez-Sarmiento, and E. Agosin. 2018. Identifying the interactions between natural, non-caloric sweeteners and the human sweet receptor by molecular docking. Food Chem. 264:164-171. https://doi.org/10.1016/j.foodchem.2018.04.113.

Ares, G., S. R. Jaeger, L. Antúnez, L. Vidal, A. Giménez, B. Coste, A. Picallo, and J. C. Castura. 2015. Comparison of TCATA and TDS for dynamic sensory characterization of food products. Food Res. Int. 78:148-158. https://doi.org/10.1016/j.foodres.2015.10.023. 
ASTM. 2008. E2164-08: Standard Test Method for Directional Difference Test. ASTM International, West Conshohocken, PA. https:// doi.org/https://doi.org/10.1520/E2164-08.

ASTM. 2012. E1697-05: Standard Test Method for Unipolar Magnitude Estimation of Sensory Attributes. ASTM International, West Conshohocken, PA. https://doi.org/https://doi.org/10.1520/ E1697-05R20.

Azevedo, B. M., F. L. Schmidt, and H. M. A. Bolini. 2015. High-intensity sweeteners in espresso coffee: Ideal and equivalent sweetness and time-intensity analysis. Int. J. Food Sci. Technol. 50:13741381. https://doi.org/10.1111/ijfs.12774.

Banach, J. C., S. Clark, and B. P. Lamsal. 2014. Texture and other changes during storage in model high-protein nutrition bars formulated with modified milk protein concentrates. Lebensm. Wiss. Technol. 56:77-86. https://doi.org/10.1016/j.lwt.2013.11.008.

Beck, S. M., K. Knoerzer, and J. Arcot. 2017. Effect of low moisture extrusion on a pea protein isolate's expansion, solubility, molecular weight distribution and secondary structure as determined by Fourier Transform Infrared Spectroscopy (FTIR). J. Food Eng. 214:166-174. https://doi.org/10.1016/j.jfoodeng.2017.06.037.

Behrens, M., W. Meyerhof, C. Hellfritsch, and T. Hofmann. 2011. Sweet and umami taste: Natural products, their chemosensory targets, and beyond. Angew. Chem. Int. Ed. Engl. 50:2220-2242. https://doi.org/10.1002/anie.201002094.

Cadena, R. S., A. G. Cruz, J. A. F. Faria, and H. M. A. Bolini. 2012 Reduced fat and sugar vanilla ice creams: Sensory profiling and external preference mapping. J. Dairy Sci. 95:4842-4850. https:// doi.org/10.3168/jds.2012-5526.

Cardello, H. M. A. B., M. A. P. A. Da Silva, and M. H. Damasio. 1999 Measurement of the relative sweetness of stevia extract, aspartame and cyclamate/saccharin blend as compared to sucrose at different concentrations. Plant Foods Hum. Nutr. 54:119-130. https://doi .org/10.1023/A:1008134420339.

Cardoso, J. M. P., and H. M. A. Bolini. 2008. Descriptive profile of peach nectar sweetened with sucrose and different sweeteners. J. Sens. Stud. 23:804-816. https://doi.org/10.1111/j.1745-459X.2008 $.00187 . \mathrm{x}$

Castura, J. C., L. Antúnez, A. Giménez, and G. Ares. 2016. Temporal Check-All-That-Apply (TCATA): A novel dynamic method for characterizing products. Food Qual. Prefer. 47:79-90. https://doi .org/10.1016/j.foodqual.2015.06.017.

Cheng, N., D. M. Barbano, and M. A. Drake. 2018. Hunter versus CIE color measurement systems for analysis of milk-based beverages. J. Dairy Sci. 101:4891-4905. https://doi.org/10.3168/jds.2017-14197.

Davis, E. A. 1995. Functionality of sugars: Physicochemical interactions in foods. Am. J. Clin. Nutr. 62:170S-177S. https://doi.org/ 10.1093/ajcn/62.1.170S.

Fujimaru, T., J. H. Park, and J. Lim. 2012. Sensory characteristics and relative sweetness of tagatose and other sweeteners. J. Food Sci 77:S323-S328. https://doi.org/10.1111/j.1750-3841.2012.02844.x.

Gerdes, S. 2012. Consumers have a thirst for protein beverages. Dairy Foods 113:22.

Guinard, J. X., and R. Mazzucchelli. 1996. The sensory perception of texture and mouthfeel. Trends Food Sci. Technol. 7:213-219. https://doi.org/10.1016/0924-2244(96)10025-X.

Hanger, L. Y., A. Lotz, and S. Lepeniotis. 1996. Descriptive profiles of selected high intensity sweeteners (HIS), HIS blends, and sucrose. J. Food Sci. 61:456-459. https://doi.org/10.1111/j.1365-2621.1996 .tb14216.x.

Harwood, W. S., and M. A. Drake. 2019. Understanding implicit and explicit consumer desires for protein bars, powders, and beverages. J. Sens. Stud. 34: e12493. https://doi.org/10.1111/joss.12493.

Hobbs, L. 2019. Sweeteners from Starch: Production, Properties and Uses. Academic Press, Burlington, MA.

Hogan, S. A., V. Chaurin, B. T. O'Kennedy, and P. M. Kelly. 2012. Influence of dairy proteins on textural changes in high-protein bars. Int. Dairy J. 26:58-65. https://doi.org/10.1016/j.idairyj.2012.02 .006 .

Imtiaz, S. R., B. Kuhn-sherlock, and M. Campbell. 2012. Effect of dairy protein blends on texture of high protein bars. J. Texture
Stud. 43:275-286. https://doi.org/10.1111/j.1745-4603.2011.00337 .x.

Kim, N.-C., and A. D. Kinghorn. 2002. Highly sweet compounds of plant origin. Arch. Pharm. Res. 25:725-746. https://doi.org/10 .1007/BF02976987.

Lawless, H. T., and H. Heymann. 2010. Sensory Evaluation of Food: Principles and Practices. 2nd rev. ed. Springer Science and Business Media, New York, NY.

Li, X. E., K. Lopetcharat, Y. Qiu, and M. A. Drake. 2015. Sugar reduction of skim chocolate milk and viability of alternative sweetening through lactose hydrolysis. J. Dairy Sci. 98:1455-1466. https: /doi.org/10.3168/jds.2014-8490.

Li, Y., K. Szlachetka, P. Chen, X. Lin, and R. Ruan. 2008. Ingredient characterization and hardening of high-protein food bars: An NMR state diagram approach. Cereal Chem. 85:780-786. https:// doi.org/10.1094/CCHEM-85-6-0780.

Liu, D., P. Zhou, X. Liu, and T. P. Labuza. 2011. Moisture-induced aggregation of $\alpha$-lactalbumin: Effects of temperature, cations, and pH. J. Food Sci. 76:C817-C823. https://doi.org/10.1111/j.1750 $-3841.2011 .02277 . x$

Liu, X., D. Jiang, and D.G. Peterson. 2014. Identification of bitter peptides in whey protein hydrolysate. J. Agric. Food Chem. 62:5719-5725. https://doi.org/10.1021/jf4019728.

Loveday, S. M., J. P. Hindmarsh, L. K. Creamer, and H. Singh. 2010. Physicochemical changes in intermediate-moisture protein bars made with whey protein or calcium caseinate. Food Res. Int. 43:1321-1328. https://doi.org/10.1016/j.foodres.2010.03.013.

McCain, H. R., S. Kaliappan, and M. A. Drake. 2018. Invited review: Sugar reduction in dairy products. J. Dairy Sci. 101:8619-8640. https://doi.org/10.3168/jds.2017-14347.

McMahon, D. J., S. L. Adams, and W. R. Mcmanus. 2009. Hardening of high-protein nutrition bars and sugar/polyol-protein phase separation. J. Food Sci. 74:E312-E321. https://doi.org/10.1111/j .1750-3841.2009.01225.x

Meilgaard, M. C., G. V. Civille, and B. T. Carr. 2016. Selection and Training of Panel Members. 5th ed. CRC Press/Taylor and Francis, Boca Raton, FL

Mitchell, H. 2007. Sweeteners and Sugar Alternatives in Food Technology. 2nd ed. K. O'Donnell and M. Kearsely, ed. Wiley-BlackWell, Oxford, UK.

Morais, E. C., A. R. Morais, A. G. Cruz, and H. M. A. Bolini. 2014. Development of chocolate dairy dessert with addition of prebiotics and replacement of sucrose with different high-intensity sweeteners. J. Dairy Sci. 97:2600-2609. https://doi.org/10.3168/jds.2013 -7603 .

Mordor Intelligence. 2018. Protein Bar Market-Segmented by Type, Source, End Product, and Geography (2018-2023). Hyderabad, India. https://www.mordorintelligence.com/industry-reports/ protein-bar-market.

Oltman, A. E., K. Lopetcharat, E. Bastian, and M. A. Drake. 2015. Identifying key attributes for protein beverages. J. Food Sci. 80:S1383-S1390. https://doi.org/10.1111/1750-3841.12877.

Ott, D. B., C. L. Edwards, and S. J. Palmer. 1991. Perceived taste intensity and duration of nutritive and non-nutritive sweeteners in water using time-intensity (T-I) evaluations. J. Food Sci. 56:535542. https://doi.org/10.1111/j.1365-2621.1991.tb05319.x.

Palazzo, A. B., M. A. R. Carvalho, P. Efraim, and H. M. A. Bolini. 2011. The determination of isosweetness concentrations of sucralose, rebaudioside and neotame as sucrose substitutes in new diet chocolate formulations using time-intensity analysis. J. Sens. Stud. 26:291-297. https://doi.org/10.1111/j.1745-459X.2011.00344.x.

Parker, M. N., K. Lopetcharat, and M. A. Drake. 2018. Consumer acceptance of natural sweeteners in protein beverages. J. Dairy Sci. 101:8875-8889. https://doi.org/10.3168/jds.2018-14707.

Quiñones, H. J., D. M. Barbano, and L. G. Phillips. 1997. Influence of protein standardization by ultrafiltration on the viscosity, color, and sensory properties of skim and 1\% milk. J. Dairy Sci. 80:31423151. https://doi.org/10.3168/jds.S0022-0302(97)76285-4.

Russell, T. A., M. A. Drake, and P. D. Gerard. 2006. Sensory properties of whey and soy proteins. J. Food Sci. 71:S447-S455. https:// doi.org/10.1111/j.1750-3841.2006.00055.x. 
Silcock, P. 2017. The basics: The functional role of sugar in food. Accessed Oct. 10, 2018. https://www.srasanz.org/sras/basics-sugar/ functionsuses-food/.

Smith, T. J., R. E. Campbell, Y. Jo, and M. A. Drake. 2016. Flavor and stability of milk proteins. J. Dairy Sci. 99:4325-4346. https:// doi.org/10.3168/jds.2016-10847.

Wagoner, T. B., H. R. McCain, E. A. Foegeding, and M. A. Drake. 2018. Food texture and sweetener type modify sweetness perception in whey protein-based model foods. J. Sens. Stud. 33:e12333. https://doi.org/10.1111/joss.12333.

Wilkinson, C., G. B. Dijksterhuis, and M. Minekus. 2000. From food structure to texture. Trends Food Sci. Technol. 11:442-450. https: //doi.org/10.1016/S0924-2244(01)00033-4.

Wright, B. J., S. E. Zevchak, J. M. Wright, and M. A. Drake. 2009. The impact of agglomeration and storage on flavor and flavor stability of whey protein concentrate $80 \%$ and whey protein isolate. J. Food Sci. 74:S17-S29. https://doi.org/10.1111/j.1750-3841.2008 .00975.x.

Yebra-Biurrun, M.C. 2005. Sweeteners. Pages 562-572 in Encyclopedia of Analytical Science, Elsevier/Academic Press, San Diego, CA.
Zeeb, B., M. Yavuz-düzgun, J. Dreher, J. Evert, T. Stressler, L. Fischer, B. Ozcelik, and J. Weiss. 2018. Modulation of the bitterness of pea and potato proteins by a complex coacervation method. Food Funct. 9:2261-2269. https://doi.org/10.1039/C7FO01849E.

Zhou, P., M. Guo, D. Liu, X. Liu, and T. P. Labuza. 2013. Maillardreaction-induced modification and aggregation of proteins and hardening of texture in protein bar model systems. J. Food Sci. 78:C437-C444. https://doi.org/10.1111/1750-3841.12061.

Zorn, S., F. Alcaire, L. Vidal, A. Giménez, and G. Ares. 2014. Application of multiple-sip temporal dominance of sensations to the evaluation of sweeteners. Food Qual. Prefer. 36:135-143. https:// doi.org/10.1016/j.foodqual.2014.04.003.

Zygler, A., A. Wasik, A. Kot-Wasik, and J. Namieśnik. 2011. Determination of nine high-intensity sweeteners in various foods by high-performance liquid chromatography with mass spectrometric detection. Anal. Bioanal. Chem. 400:2159-2172. https://doi.org/ 10.1007/s00216-011-4937-z. 